\title{
The Responsible Business
}

Corporate Social Responsibility in the Recession

By

Isaac Jordan Rodgers

\author{
A thesis \\ submitted to the Victoria University of Wellington \\ in fulfilment of the \\ requirements for the degree of \\ Master of Commerce and Administration
}

Victoria University of Wellington

2012 


\section{i. Abstract}

The 2008 financial crisis and recession crippled some of the largest businesses in the world and caused severe recession across the world. However, prior to the focus on economic recovery, social responsibility and sustainability were major themes in the business world and debate centred on the role of business in society. The key question and area for research was how the financial crisis affected this debate. This thesis uses the financial crisis to explore the role and responsibilities of business.

This research is located firmly within the literature on business and society, where the key debates centre on the role of business and the scope of business responsibilities. The literature on social responsibility has a notable gap in the fact that it does not address the impact of economic context on social responsibilities. The methodology of this paper uses a set of twentyone interviews. These interviews consisted of three sets of seven interviews with different participant groups for each set. The participant groups consisted of consumers, policy managers and business managers. These interviews were analysed for themes through the data analysis method of coding.

The findings of this paper suggest that the role of business in society should be focused on the generation of profit and that the recession or other economic influences do not change this role. These findings also suggest that although businesses are responsible only for complying with the law, they should also satisfy their customers, engage in activities beneficial to their long term interest and avoid actions which cause harm to others or undermine the long term viability of the business. The findings also imply that neither economic context nor profit, changes these responsibilities.

These findings make important theoretical and practical contributions. The theoretical contributions support the literature arguing for a limited scope on the role of business. They also argue in favour of social responsibilities being voluntary. The finding that economic context and profitability have no impact on responsibility is important in its own right, but also suggests that business responsibilities are static. This paper makes another contribution through models which are based on the findings. These models combine social responsibility with corporate strategy to show the concept of a responsible business and the difference between voluntary, compulsory and strategic responsibilities. 


\section{Acknowledgements}

The completion of this thesis would not have been possible without the help, support and participation of numerous people. A big thank you to Todd Bridgman for his supervision of my thesis, his direct and clear feedback and for his patience and commitment to my thesis especially as I started full time employment, went on a long holiday and moved to the over side of the world. Thanks also to Chris Yee for the editorial work, Liz Jackson for her suggestions and support as a fellow student and Sophia Lum, Megan Key and Tracey Wharakura for their patience and assistance in all my numerous thesis suspensions, extensions and queries.

Finally, thank you to everyone who participated in the data collection component of this research. 


\section{Table of Contents}

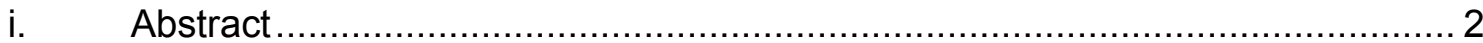

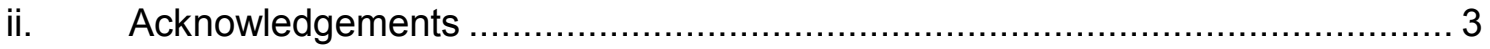

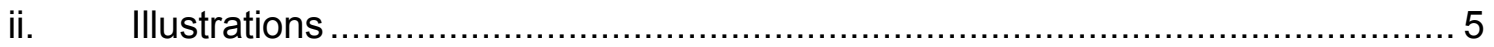

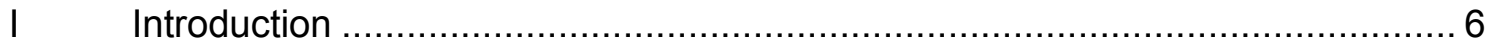

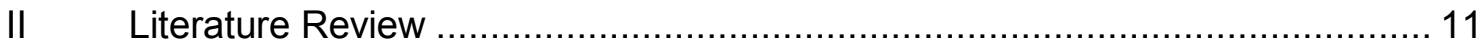

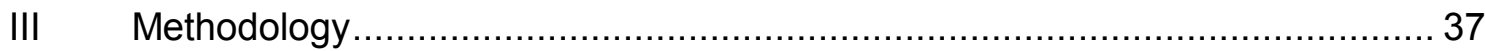

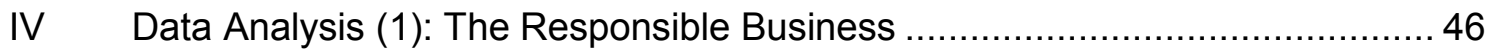

V Data Analysis (2): The Influence of the Economic Context ........................ 61

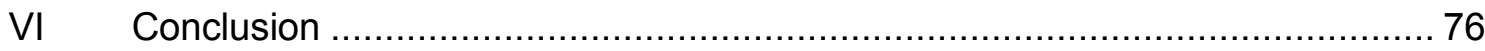

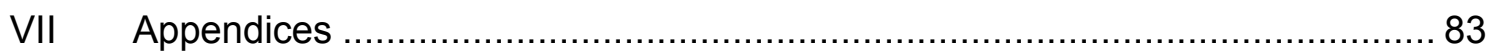

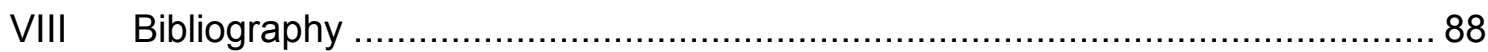




\section{ii. Illustrations}

Figure 1: Money bags and a mystery bag: the various models of responsibility. .55

Figure 2: Core and Peripheral Responsibilities. 66

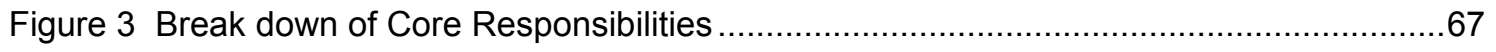

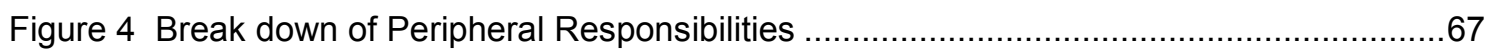

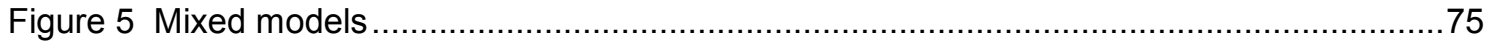




\section{Introduction}

\section{Research Context}

It has been a hard time for capitalism. Oliver Stone and Michael Moore have capitalised on the public mood by creating movies (Wall Street 2: Money never sleeps, Capitalism: A Love Story) demonising the apparent greed and reckless behaviour by companies like Bears Stearns, Goldman Sachs and Lehmen Brothers that almost brought the global financial system, and many powerful economies, to their knees. And still the financial crisis continues to undermine the recovery of many developed economies. Governments have responded to the financial crisis through a series of unprecedented bail outs, special legislation (to capture bankers' bonuses) and have begun to regulate the financial industry. The financial crisis has made elements of capitalism highly unfashionable. In fact, the French President Nicholas Sarkozy proclaimed that the financial crisis signalled the end of laissez-faire capitalism (Telegraph, 2008).

Contrast this with the atmosphere prior to the impact of the financial crisis: the global economy had gone through a huge period of growth and was booming. Huge corporate profits were met with huge bonuses and consumers concerned themselves with saving the world from global warming. Businesses flocked to become green, sustainable and socially responsible to attract these consumers. Social responsibility was fashionable. The financial crisis, however, gave weight to words such as 'excessive profit' and seemed to shift the meaning and application of social responsibility from meaning sustainable in a green context to sustaining the employment market. This shift in business focus is also reflected shifts in consumer behaviour away from luxury or value added goods toward basic goods because of the drive to save in an uncertain employment market (Abate, 2009). This 'shift in meaning' raises questions about what the public actually expect from businesses and whether the context of an economic crisis or a business' profitability affects its responsibilities.

\section{Aims and Chapter Overview}

I have written this thesis to understand more about the social responsibilities a business has to society. While there is abundant research on the role of business in society, this thesis will differentiate itself from existing research by looking at the role of business and business responsibilities through the context of the 2008 recession and financial crisis. The introduction of a factor such as economic context and others such as level of profit will allow for a richer understanding of what drives the social expectations of business. 
In this chapter I will discuss how I became interested in this topic, state my research objectives, explain where this research is located in academic literature, provide a brief overview of the research design and data analysis, explain the significance of this research, and finally provide an overview of the following chapters.

\section{Personal Interest and Objectives}

I am interested in Corporate Social Responsibility (CSR) because of my previous research into corporate strategy and CSR. In my previous research I argued a case for environmental sustainability to be included within corporate strategy (Rodgers, 2008). I completed the research just before the full force of the financial crisis started. As I began to contemplate doing my Masters I thought more about the way in which businesses would prioritise social responsibilities and whether the public or 'society' actually expected anything from them, given the severity of the recession. I also wanted to contribute to the debate on the role of business and society and at the same time, create an understanding of this situation for myself. For these reasons, it seemed like a logical choice to write my thesis on this issue.

The research objectives of this thesis are to understand more about the role and responsibilities of business and whether economic context changes or influences the role or responsibilities of business. By satisfying these objectives, I hope to be able to contribute a greater understanding about CSR.

\section{Literature}

This aim of the literature review is to explore existing literature on the role and responsibilities of business and to make a contribution to this debate by exploring what groups in society think the role and responsibilities of business are. To do this, the literature review details the key arguments and debates relating to the role and responsibilities of business in the academic fields of strategic management, stakeholder theory, business and society, business ethics and CSR.

The literature review is split into two parts. The first part discusses the role of business in society while the second part focuses on what responsibilities a business has. The first part begins with an overview of strategic management. The purpose of this is to show the context within which businesses operate and the relevance of the arguments about the role and responsibilities of business. The overview of strategic management leads into a discussion on the ability of stakeholders to influence the objectives of an organisation and the debate on which 
stakeholders a business should be accountable to. This debate is cemented by two different views: the first is that there is a special (fiduciary) relationship between management and the shareholders which overrides the interests of other stakeholders. The opposing view is that businesses should balance the interests of stockholders and stakeholders.

The debate on stakeholder management leads to one of the core parts of this literature review, which explores what the purpose of business is and what business are responsible for. On one side there are academics and businessmen who argue that the purpose of business is to make money and that businesses achieve social good by making money (Friedman, 1970; Freeman \& Phillips, 2002). On the other side there are academics and businessmen who argue that the purpose of business goes beyond the maximisation of profit; that businesses should be responsible for some sort of social good. This debate is addressed in a New Zealand context through the public debate between Roger Kerr, Norman Barry and Dick Hubbard. The debate on the role of business is further explored through literature on political ideology, morality, ethics and religion to reason why some sectors of society think that businesses have a role beyond profit.

The second part of the literature explores the responsibilities of business and also explores the context of the 2008 recession and credit crisis. The literature on the responsibilities of business is initially examined by looking at the field of business ethics and prolific examples of corporate failures or criminal actions, which have created a drive for transparency, business ethics and a movement toward CSR. The discussion on corporate responsibility is another core part of this literature review. The focus of the CSR section is on the meaning of CSR, what the responsibilities of business are, and the flaws of existing research on this topic as well as a discussion on different approaches to CSR, one of which combines CSR with the creation of business value. The final part of the literature review brings in the context of the 2008 financial crisis and recession. This section identifies the core gap in the literature; it discusses the 2008 financial crisis and states that there is little existing research on how factors such as a recession can influence what people think the role and responsibilities of business are.

\section{Research Design}

The philosophy of this research is taken from the perspective of an objective functionalist (Burrell \& Morgan, 1979). The functionalist perspective focuses on the pursuit of an answer or the answer to a social issue. The focus of this research is to investigate the role of business in society and social responsibilities (Gioia \& Pitre, 1990). An objective functionalist's perspective would usually involve a quantitative methodology (ibid). However, the aim of this research is to 
gain an understanding of the social responsibilities of business by exploring participant responses. On this basis, a qualitative method (despite its apparent conflict with an objective paradigm) was chosen due to the desire to understand more about social responsibilities, which are, of course, social phenomena.

The qualitative data collection method for this research was in the form of interviews. A series of interviews with three different groups of participants was held in Wellington, New Zealand. The three different groups of participants were composed of consumers, policy makers and business managers. The rationale for selecting these three participant groups was that they allow a cross perspective view of society in that they form the three main representative groups (from a business-society perspective) in society. All of these interviews were conducted confidentially in a private setting. The interviews were semi-structured to ensure a high level of consistency, but also to allow the possibility for participants to describe ideas or examples that they thought were relevant or explained their views.

\section{Data Analysis}

This thesis seeks to explore what participants thought the role and responsibilities of business were before exploring if or how factors such as economic context or level of profit influence responsibilities. In the first analysis chapter, titled 'the responsible business', the responses from participants are analysed and coded to build themes and to explore what participants thought the role of business was and responsibilities business have. The first analysis chapter presents a model, based on the prevalent themes in the results, of the 'responsible business'. This sets the framework for the second chapter where economic context and level of profit are used to explore whether the roles and responsibilities of business change. In this chapter another model is built to understand core and peripheral responsibilities. Together, these chapters will provide a greater understanding of what society expects from business and whether factors such as the economic environment have any impact on the social responsibilities of business.

\section{Relevance of Research}

This research is relevant for theoretical, practical and political reasons. From a theoretical perspective, this research aims to deliver three core contributions to literature. The first is to provide a greater understanding about the role of business in society. The second is to provide a greater understanding about what the responsibilities of business are. The third core contribution to literature is to explore whether factors such as economic context and profit influences a business' social obligations. 
From a practical perspective, this research provides a framework by which businesses wishing to be socially responsible can do so strategically. The framework provided in this research portrays social responsibilities as a set of mandatory responsibilities, strategic responsibilities and voluntary responsibilities, depending on the desire of the business owner or manager. From a political perspective, this research is important because it aims to define and limit the scope of business responsibilities into responsibilities that can relate to profit or wealth generation.

\section{Thesis Outline}

This chapter has introduced the topic of my thesis, the research context, my aims as well as an overview of the key parts of the thesis. There are a further five chapters. Chapter two reviews existing literature and builds a framework of literature from corporate strategy to social responsibility for the purpose of this research. The gaps are identified in the existing research which gives relevance to the aims and finding of this research. Chapter three details the way in which data was collected and analysed as well as detailing the research philosophy that guided the data collection. This chapter also provides detail and justification as to why particular methods were chosen over others. Chapter four is the first results and discussion chapter. In this chapter the first and second research questions are addressed and a framework is built which details the role and responsibilities of business (without the introduction of any economic factors). This second part of this chapter discusses the findings as they relate and contribute to literature. Chapter five is the second results and discussion chapter. In this chapter the third research question is addressed (the findings explore whether the role and responsibilities of business are influenced by the recession). The second part of this chapter discusses the findings as they relate to the previous chapter as well as outlining how the findings contribute to literature. Chapter six concludes this thesis. This chapter summarises this thesis and focuses on key findings, how they answer the research questions as well as the key contributions to literature. In addition to this, chapter six provides limitations of this research as well as opportunities for future research. 


\section{Literature Review}

\section{Introduction}

During the recession, Hyundai's advertising had an interesting selling point on its after sales service. If a customer was to buy a car from a Hyundai dealer and was to subsequently lose their income within 12 months of the purchase, Hyundai promised to cover repayments for the first three months, and if the purchaser was still unable to find employment, then the car could be returned (Hyundai Assurance New Zealand, 2009). This promotion intelligently captured the mood of the customer who was interested in purchasing a new car but was also afraid of more debt obligations in an unstable employment market. The most interesting element of this promotion is whether it was intended to be purely promotional or whether it an example of CSR. It might be both. But are such promotions or social actions indicative of a more understanding business in the context of tough times or is this merely an example of a smart business exploiting the mood of the market? Or does economic context influence the social expectations of business?

Over the past couple of years we have witnessed one of the greatest periods of global economic decline since the 1930s. The above example shows a business using the recession strategically to market its product. But do the public expect businesses to be as (or more/less) charitable or socially responsible in a recession as in a time of economic growth? The purpose of this literature review is to explore the theory of social responsibility and to understand the ideas, issues and debates which have either pushed for a greater social role for business in society or have tried to restrict it. This literature review also aims to identify the gaps and debates in literature which this research aims to contribute to. The following literature review is read as one chapter but is split into two parts. These two parts have a different focus. The first part of the literature review explores literature that relates to the role of business in society while the second part explores literature that relates to corporate social responsibility and the responsibilities of business. Together these parts present an argument on how the role of business has developed and how it might be changing as a result of the recession and address the gaps in existing literature. 


\section{Part 1: The Role of Business}

\section{The Strategic Context of Business, the role of business and business responsibilities}

Hyundai is in the business of making money. In its campaign to sell vehicles and be seen to be socially responsible, Hyundai turned a threatening macroeconomic environment into part of its strategy to sell cars. Strategic management is about the long term direction and capability of business. It provides a way to arrange resources and competencies in an attempt to meet a particular need (Johnson, Scholes, \& Whittington, 2005). The design school approach to strategic management, which adopts the above definition, is supported by leading academics in corporate strategy (Andrews, 1980; Ansoff, 1991; Schendel, 1985). The above definition of strategy is adopted as the meaning for strategy or strategic management in this literature review because of its recognition of strategy as a planned action, which aligns organisational capabilities and resources with macro-environmental forces. The design school approach also ties closely into the other concepts in this literature review and shows how CSR can be strategic.

The environment a business operates in must be understood. An essential tool within the strategic management literature is PESTEL. PESTEL is a framework, which examines the macroeconomic environment by looking at political, economic, social, technological, environmental and legal factors which can positively or adversely affect a business. The Hyundai example shows effective use of economic and social environment factors into strategic planning. Environmental factors such as these need to be understood and monitored; this may be best accomplished by researching the market or communicating with stakeholders relevant to the PESTEL categories. At the same time a business must be aware of what it is capable of and how to make best use of its resources. This is how a business achieves competitive advantage (Johnson, Scholes, \& Whittington, 2005). Knowing the environment and business capabilities is important. Freeman states that "The point of strategic management is in some sense to chart a direction for the firm" (1984, p. 46) while Bird, Hall, Momente and Reggiani add that strategic management aims to maximise the long term value of a business (2007).

However, part of ensuring the long term value of a business is by understanding how a business and interest groups can affect each other. Freeman suggests that any group which can affect the direction or implementation of strategy be considered in the strategic management approach (Freeman, 1984). This connection between strategy and stakeholder management is not new, it has been made by numerous authorities in the field of strategy. Kenneth Andrews, for instance stated that there was a connection between strategy and organisational resources to 
shareholders, employees, customers and communities (Andrews, 1980). Businesses that incorporate stakeholders into strategy may build better relationships with customers, NGOs and governments and as a result avoid regulation. The following section looks at the literature on stakeholders, how they can impact on business objectives and how stakeholder management relates to the debate on the role of business.

\section{The Stakeholder Debate}

In May 2006, Telecom New Zealand, at the time New Zealand's largest publicly listed company by stock valuation, lost one quarter of its stock value after a leaked government document indicated pending legislation that would effectively neutralise Telecom's monopoly over telephone infrastructure (and also its internet services) (Young, 2006). The unbundling was the result of uncompetitive pricing from Telecom which resulted in lobbying from consumer pressure groups, telecom's competitors, government competition regulators (the Commerce Commission) and ultimately legislation (Young, 2006; Consumer, 2006). Regulators have enormous power which can redefine or shift the balance of an industry and are therefore the biggest source of political and social pressure to companies (Beardsley, Enriquez, \& Nuttal, 2008). In the above example, Telecom exploited its monopolistic position and ignored or did not understand the demands placed on it by interest groups directly affected by its abuse of its monopoly.

Stakeholder theory is about looking beyond the relationship with shareholders to the relationship between the organisation and a broad set of actors including customers, employees, governments and NGOs (Barnett, 2007). This literature on stakeholder theory is important because it helps us to understand the role of business by exploring whom a business is accountable to. At the heart of this literature there is an ongoing debate which focuses on which stakeholders a business is accountable to. This section on stakeholder theory looks at the rise of the term, the various meanings, and the application of stakeholder theory as well as the debate about the accountability of businesses to various stakeholders.

The stakeholder debate initiated in the 1970s, where Gamble and Kelly (2001) link the beginning of the debate to the fall of the British and American economies (relative to the rise of the Japanese economy). There was concern that focus on the short term profitability was limiting long term growth, an area where the Japanese and Germans were succeeding (Gamble \& Kelly, 2001). In other words, the focus on returns was undermining the long term viability of AngloSaxon businesses. This resulted in corporations taking lessons from emerging economies about long term growth and in some cases extending business focus beyond that of just short term profit (Gamble \& Kelly, 2001). Goodpaster (1991) suggests that the word 'stakeholder' was 
created to play on the word 'stockholder' and demonstrate that there are groups, beyond stockholders, who have an interest or stake in the organisation. The classical definition of stakeholders is: "those groups without whose support the organisation would cease to exist" Stanford Research Institute, 1963 cited in (Donaldson \& Preston, 1995, p. 72). According to this definition, only customers, shareholders and government are stakeholders, while employees, community and suppliers are stakeholders depending on the context of the business. However, Freeman elaborated on the concept of Stakeholder as "... any group or individual who can affect or is affected by the achievement of the organisation's objectives" (Freeman, 1984, p. 46). This wider definition of stakeholder potentially encompasses any person or organisation. This definition has been narrowed by some academics, requiring 'legitimate interest' in the organisation (Donaldson \& Preston, 1995). But what is legitimate interest? The authors do not elaborate. If the example of Telecom is reintroduced, supposedly all individuals or groups who felt they were affected by Telecom's actions, in a positive or negative manner, have a legitimate claim. But would the more adversely affected have a more legitimate claim? If Telecom's exploitation of its own infrastructure was in the pursuit of making profit to maximise shareholder value, then how much attention should it pay to its competitors who rely on its infrastructure and the customers of these competitors? Donaldson \& Preetson argue that attention must be given to the legitimate interests of all stakeholders in policy and decision making (1995).

One of the biggest failings of stakeholder theories is that there is no direction on how to overcome conflicting interests (Bird, Hall, Momente, \& Reggiani, 2007). Donaldson and Preston point to claims that no set of stakeholder interests override another's (1995). One example of stakeholder conflict was where a corporation sought to improve its relations with one stakeholder group and as a consequence upset others stakeholders. In 2005 Microsoft supported an antidiscrimination bill in support of its gay and lesbian employees (the bill aimed at preventing discrimination against gays and lesbians). Microsoft's support of this bill improved its relationship with its gay and lesbian employees as well as human rights groups, but it caused Rev. Ken Hutcherson (and his group) to threaten a boycott against Microsoft's products because it was 'engaging in social engineering' (Barnett, 2007; Cook, McGann, \& Pope, 2005). Microsoft then shifted its stance to neutrality, which was allegedly because of Hutcherson's influence (Teather, 2005). However, this new neutral stance damaged Microsoft's relationship with the staff they had initially tried to support. Once again Microsoft changed its stance in support of the bill, which had failed to pass into law (Cook, McGann, \& Pope, 2005). This annoyed Microsoft's gay employees and the conservative groups, the latter who claimed that Microsoft was overstepping its bounds, engaging in social engineering and imposing on its employees who did not support the bill. In the above example, the agendas of both stakeholder groups are clearly in 
conflict with each other. The organisation, in this case Microsoft, had to choose between its principles and its business. Microsoft did neither.

The separation of stakeholders into primary and secondary stakeholders may help to make sense of the more important and less important stakeholders thereby creating a framework through which conflicting interests can be prioritised. Primary stakeholders are defined as stakeholders who are an integral part of the existence of the company (Ihlen, 2008). This definition of a primary stakeholder conforms to the Stanford Research Institute's initial definition. A secondary stakeholder is a stakeholder which is affected by the activities of the business, directly or indirectly (Ihlen, 2008). Alternatively stakeholders can be ranked by urgency, power and legitimacy (ibid). Another way of understanding stakeholders is through normative and derivative means. A normative stakeholder is one to whom the organisation has a moral obligation to, this would include customers, employees and shareholders, while a derivative stakeholder is a stakeholder that may have influence on the organisation and its stakeholders (Ihlen, 2008). However, the task of actually ranking stakeholders relies on the organisation's perception of stakeholders. Ranking stakeholders and then using the ranking as a base from which to handle conflicts of interest may not be the best way to reconcile conflict as it arbitrarily resolves a conflict based on a similar arbitrary ranking. Stakeholder analysis and stakeholder synthesis provide another means for understanding stakeholders.

Goodpaster (1991) outlines a two prong stakeholder analysis followed by stakeholder synthesis. Stakeholder analysis starts by first identifying the parties who have an interest or stake in the organisation. The second part is to identify the negative or positive impact the proposed decision has on each identified stakeholder. Interestingly, Goodpaster states that stakeholder analysis is morally neutral as it merely identifies who is interested in the business and what they have to gain or lose. However, stakeholder synthesis is not morally neutral. Stakeholder Synthesis goes a step further by looking at stakeholders instrumentally; looking at how they affect the organisation's long term or short term success (Goodpaster, 1991). Stakeholder analysis along with stakeholder synthesis then gains a strategic element to it. One approach to stakeholder synthesis is semi-formulated by Goodpaster where a manager should engage in actions that "1) maximise the benefits and minimise the costs to the stockholder group, short and long-term, and (2) pay close attention to the interests of other stakeholder groups that might influence the achievement of (1)" (1991, p. 60). On this point, Freeman (1999) cited in (Freeman \& Phillips, 2002) suggests that managers need to give direct attention to stakeholder relationships in the interests of maximising shareholder wealth or profit. This is also the instrumental view. This means that the interests of stakeholders need to be addressed in order to prevent any harm to shareholders. However, this does not imply that stakeholders need to be treated equally 
(Freeman \& Phillips, 2002). The logic behind identifying stakeholders; by finding out who they are, what they stand to gain (or lose) and what impact they can have on the organisation, is simple and undeniable. The success of the organisation depends on its relationship with stakeholders (Ihlen, 2008). Freeman and Phillips also state that "stakeholder theory is a managerial conception of organisational strategy and ethics" (2002, p. 333). The writers go on say that corporations need to understand the social effects of their activities and that the economic consequences of these effects need to be understood. Stakeholder theory is about how an organisation manages its relationships with important groups (stakeholders) that can affect the organisation's purpose (Freeman \& Phillips, 2002). The role of the manager therefore is to try to balance, manage and influence the relationships among these groups and businesses (Freeman \& Phillips, 2002).

Freeman and Phillips argue that the political concept of Libertarianism is related to stakeholder theory. Libertarianism is a form of capitalism with patriarchs such as John Locke and John Stuart Mills. The key concepts relevant to this paper include private property rights and the concept of moral autonomy, which is also known as the pursuit of happiness (Freeman \& Phillips, 2002; ). The initial link between libertarianism and stakeholder theory is made by referring to the right of persons to do as they please, provided it does not interfere with someone else's wish to do as they please or, alternatively, that person's right not be interfered with (ibid). This means that business should operate in a way where profit can be maximised without interfering on the rights of others. Freeman and Phillips support this by saying "it is a hallmark of libertarian views that voluntary acts among consenting adults ought to count as morally permissible, provided that they impose no substantial costs on any third party" (1984, p. 335). Freeman and Philips go on to say that "since managers are boundedly [sic] rational, and since the world is uncertain [managers] must pay attention to the consequences of their actions on others; to ignore others is to put oneself and one's company beyond the pale of morality and ethics" (2002). The point is not that businesses are generally accountable to other stakeholders, but that where a business infringes on the rights of others, it is accountable to the stakeholder to make things right. This means that businesses should operate in such a manner that no harm is caused to stakeholders. If harm is caused to stakeholders, the business has a responsibility to rectify the harm caused to the third party (Freeman \& Phillips, 2002).

Another approach to stakeholder management is to look at the fiduciary relationship owed by management to the shareholders. The duty means that there is a special relationship between the manager and the shareholder, where the manager must act in the interests of the shareholder. This means that other stakeholder concerns are secondary to those of shareholders (Goodpaster, 1991). In contrast, the multi-fiduciary approach argues that a 
business has a special relationship to multiple stakeholders and not just shareholders (Goodpaster, 1991). However, this concept is incompatible with the argument that there are special obligations owed to shareholders. At the centre of western capitalism is this belief that the obligations of agents to shareholders are different from those to third parties (Goodpaster, 1991). Ruder (1989) cited in (Goodpaster, 1991) claims that the multi-fiduciary approach dilutes the fiduciary obligation to shareholders. Goodpaster weighs up Ruder's claim by stating that a multi-fiduciary approach is possible if we allow it, but it will effectively make stakeholders very similar to shareholders. Goodpaster goes on to say that the implications of this would be radical because entrepreneurial risk taking would turn to paralysis (balancing of demands) and the conflicting goals of a multi-fiduciary approach would dilute the purpose of the business and result in "the conversion of the modern private corporation into a public institution" (Goodpaster, 1991, p. 66). Porter and Kramer (2007) acknowledge the importance of stakeholders in decision making, but note that most stakeholders do not understand the complexities of the corporation.

Returning to Freeman and Phillip's linking of libertarianism and stakeholder theory; if property rights must be respected and shareholders own the corporation then managers must act in the interests of the property owners (Freeman \& Phillips, 2002). In addition, by entering in a voluntary agreement with the corporation the manager has a personal responsibility to serve the corporation in the interests of the cause it is contracted to, and in this case, the property owners (Freeman \& Phillips, 2002). Not surprisingly, the multi-fiduciary approach to stakeholder management is perceived by some academics as an agenda which "would destroy the clear objectives which the shareholder value model provides for managers ... and [cause] potential confusion between [business] objectives" (Gamble \& Kelly, 2001, p. 113). The resistance against multi-fiduciary relationships and, more broadly, against stakeholder theory could be attributed to the fear of the primacy of shareholder wealth being relegated to that of social welfare.

This section on stakeholder literature has discussed various views on stakeholder theory. The key themes being that stakeholder management is an important part of strategic management, that there is debate between those that argue that businesses are accountable only to stockholders and those that think businesses should be accountable to society. There is also support for the view that businesses should take accountability for how their actions impact others. This debate now moves onto a related issue about who a business is responsible to in terms of the role of business in society. The following section explores the role and purpose of business in the New Zealand context. 


\section{The debate on the role of business in society}

In 1970, Milton Friedman wrote a commanding article about the role of business. Friedman, roused by some businessmen expressing sentiment for the idea that businesses had social responsibilities, argued that the social responsibility of business was the maximisation of profit and that the corporate executive is bound by a fiduciary duty to serve in the interests of the shareholder. This meant that any charity or contributions to social welfare without the consent of shareholders, was an abuse of the executive's position and a tax on shareholders (Friedman, 1970). This view is supported by numerous writers including Gamble and Kelly (2001) and Vogel (1991) who state that company directors owe a fiduciary duty to shareholders to perform their job in the interest of shareholders because shareholders own the enterprise and the risk that follows (Gamble \& Kelly, 2001).

In New Zealand, during the late 1990s, the role of business in society was heavily debated between Dick Hubbard, an Auckland businessman and advocate of social responsibility and Roger Kerr, head of the business round table, and Norman Barry an academic, who both argued against the idea that businesses have a duty to stakeholders and society generally. Hubbard, referring to Freeman (1970) and Kerr (1998), claims that the business of business is more than business (Hubbard, 1999). Hubbard gained attention for his 'social responsibility' when he paid for ninety of his workers to go to Samoa for a long weekend (Caddie, 1998). Hubbard, an advocate of the triple bottom line and something he calls the 'corporate soul' where decisions are made from the 'head' as well as the 'heart', argues that a business has more to its purpose than merely making money (Caddie, 1998). An example of this is where Hubbard employed a man who had been out of work for seven years (because he had been out of work for seven years). However, Kerr and Barry think that the pursuit of social welfare distracts from the purpose of business. In Business as a Vocation, Kerr states that "one of the mistakes of our time is to divert people or organisations form the good they do for society by performing their roles well and to assign them instead the problematic role of trying to do good directly" (2004, p. 8). According to Kerr (and Friedman) the responsibility of a business is to follow the law and satisfy ethical standards in a way where the value of the business can be maximised in the long term. This is in contrast to Hubbard's position where Businesses are supposed to give something back to the community.

Like Friedman, Kerr sees business as a voluntary exchange, motivated through self-interest, but with mutual gain. Both parties benefit. Businesses earn money by selling products or services for which people are prepared to exchange for money (this is called the principle of stakeholder cooperation) (Freeman \& Phillips, 2002). On this basis, a profitable business is one which 
continues to benefit society through providing a service or product in a mutually beneficial exchange (Kerr R. , 2004). Kerr sees this as the chief social role of business (Kerr R. , 2004). Kerr refers to this as the competition amongst firms to best serve the community (Kerr R. , 1998; Kerr R. , 2004). Barry defends this interaction by saying that engaging in business cannot be any less moral than other human activities, merely because they are self-interested (Barry N. , 1999). Kerr then refers to calls from Hubbard for businesses to balance shareholder interests with those of other stakeholders and to donate profit to charity or community causes. Kerr observes that investors who do not care about a return on their investment are as rare as teachers who do not care how much they are paid (Kerr R. , 2004). Hubbard responded to this in a newspaper editorial by claiming that stakeholder theory is the "realisation that managers have moral and ethical responsibilities to all stakeholders in a business and that the shareholders are not the only stakeholder" (Hubbard, 1999).

Kerr and Barry question how this can be reconciled with, firstly, the fact that business is not a charity, secondly, that company directors act as agents for the shareholders, the money is not theirs and, thirdly, that there is no guidance on how to meet conflicting stakeholder claims (Kerr R. , 1998; Barry N. , 1999). On this point, Kerr refers to the state of New Zealand's (formerly) government owned businesses, such as Telecom New Zealand, where profit was subordinated and the result was inefficiency and unaccountability (Kerr R. , 1998). Recently, Kerr has said that taking the focus away from shareholder value would allow organisations to escape accountability for poor financial performance (Kerr R. , 2004). Similarly, Barry suggests few people would put money into a company which is accountable to multiple causes. This is because ownership rights would be diluted (Barry N. , 1999). Kerr quotes a member of the public who implies that Hubbard has misunderstood his position because he, as an owner of private enterprise, is able to make donations, while managers of companies do not have the same freedoms (as it is not their money) and would effectively be taxing shareholders (Kerr R. , 1998). The only way social responsibility would not be a tax, according to Kerr, is where donations are used for publicity and where it becomes public relations and has a commercial goal (Kerr R. , 1998).

However, Kerr and Barry do not disagree entirely with stakeholder theory. Kerr states that customers and employees are examples of important stakeholders whose needs must be observed (Kerr R. , 1998). In addition, businesses need to weigh up investor depends with how their business activities impact on the community in which they operate (Kerr R. , 2004). This is in line with the 'Nemo dat principle' - where investor expectations cannot be inconsistent with ethical expectations of the community (Goodpaster, 1991). However, Barry balances this by stating that businesses should not be expected to go beyond minimum legal requirements, 
although any voluntary action beyond legal minimum is respectful (Barry N. , 1999). Perhaps the greatest statement of Kerr's opposition to Hubbard's stakeholder theory is "the whole language of stakeholding is of entitlement: various groups are encouraged to see themselves as entitled to share in the rewards of the firm, or of society generally" (Kerr R. , 1998, p. 10).

The role of business in society seems to have different meanings to different groups. On one side is a group that claims that profit needs to be balanced with the promotion of greater social good, while on the other side there is a view that businesses do not have social responsibilities other than statutory obligations to shareholders, compliance with the law of the land and the satisfaction of a minimal ethical framework. Stakeholders are also an important part of the argument. Those who advocate social responsibility argue that business should show responsibility toward all stakeholders, while those advocating a conservative focus understand the importance of stakeholders, but argue that the interaction with stakeholders should be related to profit or business activities. In an article in the McKinsey Quarterly, the writer declared both the Milton Friedman view of business and the stakeholder view of Hubbard, as old fashioned (Davis I. , 2005). Davis claims that the Friedman perspective results in businesses acting defensively to social issues, where they should be proactively engaging in social issues and agendas. These social issues indicate that there are social needs and demands which are not being satisfied. If businesses see these social needs instrumentally (how they can make money out of social needs) then they can gain an advantage over their competition (Davis I. , 2005). Davis suggests that the ultimate purpose of business today as "the efficient provision of goods and services that society wants" (2005, p. 112).

A theme that is quite common through the writings of Friedman, Kerr and Barry is the admiration for voluntary action by individuals who engage in activities that help the community or further social welfare. However, Kerr also makes a parallel between stakeholder theory and alternative political ideologies and implies that the multi-fiduciary approach is like socialism. However, the fundamental issue is not whether a multi-fiduciary or stakeholder approach is socialist, but why some people expect such a wide social role for business. Political ideology may play its part in this, but so does morality. There is a strong theme in literature that the pursuit of profit and business is immoral, unethical and incompatible with good society (Schroeder, 2002). Morality or religion also has a significant weighting on the stakeholder argument, which is particularly problematic if the role of business is to make money. Western Society is founded on JudeoChristian beliefs (Vogel, 1991; Hurn, 2008). Religion is an important aspect of culture which controls values, behaviour and beliefs (Kennedy \& Lawton, 1998). The Latin phrase "Homo Mercator vix aut nunquam potest Deo placer. Et ideo nullus Christianus debet esse Mercator, aut, si voluerit esse, proiiciatur de ecclesia Dei” translates to: because a trader cannot please 
God, Christians should not be traders and if they are they should be thrown out of the church (Zimmerman, 1996, p. 170). The idea at the time seemed to be that there was no legitimate role for business in society. Similarly, Saint Augustine said that "the businessman may conduct himself without sin, but cannot be pleasing to God" (Vogel, 1991, p. 103). Saint Thomas also thought that trade for profit was morally suspect as it would cause unequal distribution of wealth (Vogel, 1991; Paderon, 1991). The Bible refers to a point where Jesus overturns the tables of merchants and money traders operating in a temple, with Jesus saying "My temple will be called a house of prayer. But you are making it a hideout for thieves" (Bible Society, 1976, p. Matthew 21:12). Similar famous verses include "the love of money is the root of all evil" (Bible Society, 1976, pp. 1st Timothy 6:9-11) and "it is easier for a camel to fit through the eye of a needle than for a rich man to enter into the Kingdom of God" (Bible Society, 1976, p. Mark 10:23). The Greek philosopher Aristotle made a distinction between noble and ignoble pursuit: talent or skill in private use appeared to be noble, while talent or skill in the pursuit of profit was not (Wren, 2000). Similarly, the Church thought it wrong for someone to be paid interest on a loan since the money had not been improved in any way. The pursuit of profit was immoral and went directly against religion. The prevalent view of the time was that commerce was rooted in extortion rather than exchange (Vogel, 1991; Paderon, 1991).

The protestant reformation removed the immorality from profit making and even sanctified it. This meant that protestant merchants were able to run a moral business (Vogel, 1991). Business now had a legitimate and moral role, and its role was to make money. Accordingly, financial success was perceived to be a sign of God's favour. This was the protestant ethic and it helped to legitimise capitalism. Prior to capitalism wealth was acquired by taking it from someone else; it was a zero sum game. Capitalism, in contrast, creates wealth in a way that benefits both the party selling the product or service and the other party which is paying for it (Kerr R. , 2004). Self interest is at the heart of capitalism. Capitalism is a system based on mutually beneficial agreements that are entered into out of self interest (Vogel, 1991; Kerr R. 2004). This concept of self interest is important: if a company sells products out of self interest, enters into contracts with suppliers out of self interest, then why would it engage in socially responsible actions unless there is some element of self interest? This may be the reason why there is scepticism of organisations that advertise how they have been ethical or socially responsible. It could be viewed as bluffing, white wash or promotion. On the other hand, what is wrong about self-interest? Should businesses be expected to act in a way where there is no element of self interest? If a business was to act out of its interests it would be hard to argue that it was aptly serving its shareholders. 
Other writers claim that there are mixed motives to ethical decision making, that there is more than self-interest involved (Di Norcia \& Tigner, 2000). They argue that there are numerous motives including "financial, practical, administrative, technological, economic, competitive, corporate, organisational, social, personal, and ethical concerns" (Di Norcia \& Tigner, 2000, p. 3). However, each of these concerns or interests, in the long term, should serve the profit maximisation of the organisation and are ultimately, although sometimes indirectly, selfinterested actions. We engage in mutually beneficial agreements as individuals and businesses because it causes an improvement to our personal wealth or possessions. We do not, generally, create businesses to sponsor a charity or to provide employment to the seasoned unemployed. However, some people are not comfortable with the thought that our economic system is based on the pursuit of self interest (Vogel, 1991). However, the meaning of self-interest can include the interests of those important to you, such as family and friends. Similarly, a business which engages in self-interested actions is likely to engage in activities that ensures its future survival. Self-interest does not just mean the maximisation of profit, but rather the protection of the circumstances and context which allow the business to continue to maximise its profit.

This section has focused on the role of business by looking at the debate in New Zealand between advocates for and against businesses being accountable to multiple stakeholders. It has also looked at how these views relate to wider social and political views. In addition to this, it has shown how societal views have moved from demonising the pursuit of profit to making it almost virtuous (exceptions exist of course). It has also addressed the wider meaning of self interest. However, there is still no clear picture or consensus on what the role of business is and how or whether the recession would influence a change in the role of business. This shall be explored as a research question in the later parts of this thesis. The following part to this literature review explores the responsibilities of business by looking at the literature on what has influenced the rise of CSR including examples of unethical corporate activities as well as the different views and applications of CSR. 


\section{Part 2: $\quad$ The Responsibilities of Business}

\section{Ethical Influences}

Tamiflu, a product of Swiss pharmaceutical giant Roche, is the apparent, albeit unproven, treatment for Avian Flu and Swine Flu (H1N1). Prior to the threat of Avian influenza Tamiflu had global sales of $\$ 76$ million (US) compared to sales in 2005 of over $\$ 1$ billion (US) as a result of the fear over a global pandemic (Mokhiber \& Weissman, 2005). Government and consumer demand overwhelmed supply and a solution would have been to grant licences for other companies to produce the drug. However, Roche chose not to licence the drug for greater supply and justified their decision by saying that the process of creating the drug was dangerous or too complicated for other pharmaceutical companies to make. Roche also claimed that there was a shortage in supply of a key drug used in making Tamiflu, meaning it would take two or three years for any licensee to add to supply (Mokhiber \& Weissman, 2005). However, these justifications were found wanting when an Indian pharmaceutical managed to reverse engineer the drug and claimed it would be able to start production shortly (Mokhiber \& Weissman, 2005). The behaviour of Roche, at a time when a global pandemic was possible, was self-interested, but ultimately very embarrassing. By cementing a chronic shortage of supply, Roche chose to mislead consumers, competitors and the World Health Organisation while maintaining high margins (Mokhiber \& Weissman, 2005). Could self interest be the reason behind why Roche chose to prevent licensing and therefore maximise profit? Or would self interest (in the longer term) have meant that Roche would have licensed the drug to protect its intellectual property rights, while increasing global supply of Tamiflu and avoiding a public relations disaster? In this case it seemed that the desire for short term profitability overrode the long term interest of the business.

Ethics is the discipline dealing with what is good and bad, and right and wrong or with moral duty and obligation (Hurn, 2008). The word itself is derived from the Greek word ethikos meaning character (Vogel, 1991). Ethics are relative and unique to each society and are represented through religion, traditions, family, identity and cohesion (Hurn, 2008; Hofstede, 1984). Research suggests that a large amount of the American public believe that companies behave irresponsibly to increase profits (Vogel, 1991). The idea that "anything goes" and "buyer beware" have given an impression that business is about pushing the boundaries of the law and getting away with whatever they can. This has given business and capitalism a bad image (Freeman \& Phillips, 2002). The negative activities of some corporations of the past decade have not helped this. It is unsurprising that some people equate the pursuit of profit with unethical or immoral activities. 
However, some business activities have not been a question of ethics, but of law. American corporations have proved quite apt at this in the last decade. The Enron collapse and the fallout which divorced Arthur Anderson from existence are well known examples of this. KPMG (a professional services firm) has engaged in illegal activities that are not as well known. In August 2005, KPMG was charged with the creation of the largest tax shelter fraud ever created, which generated billions in false tax loses, to which the firm admitted (Mokhiber \& Weissman, 2005; Reuters, 2009). However, there was no conviction, KPMG was fined $\$ 456$ million in fines and faced a deferred prosecution (Internal Revenue Service, 2005; Mokhiber \& Weissman, 2005). One of the reasons why there was no conviction was to avoid the collapse of KPMG, or a repeat of what happened to Arthur Anderson (Mokhiber \& Weissman, 2005). The KPMG case has since been to trial with the conviction of a tax manager, who was fined $\$ 6$ million and sentenced to 10 years jail, while a tax partner was sentenced to 8 years prison and fined $\$ 3$ million (Reuters, 2009). Long term self interest would have meant that fines and prison would be avoided. KPMG and Roche are examples of businesses behaving unethically or illegally where there is no indication of the struggling financially. The response of numerous multinational businesses to these high profile instances of poor corporate governance has been to create a code of conduct that details ethical standards and shows that the business is committed to better business behaviour (Carrigan \& Atalla, 2001).

The above examples demonstrate instances where businesses have either broken the law or appear to have acted immorally. But what is an ethical business: is it one which satisfies moral and ethical expectations in the community? Can British American Tobacco be an ethical business if it donates to a charitable trust that promotes strong communities, sponsors the 'Keep New Zealand Beautiful Society' as well as the Napier Art Deco Trust? (British American Tobacco (New Zealand), 2007). These examples of 'social responsibility' may explain why British American Tobacco ranks highly on some social responsibility rankings (Kolk \& Pinkse, 2007). In fact, it has been recommended that organisations in industries with bad reputations (like tobacco, chemicals and oil) lead the field in social responsibility (Mohr, Webb, \& Harris, 2001). However, in spite of Britain American Tobacco's best intentions and deep pockets it knows its product is addictive, poisonous, marketed to be 'chic' and, combined with other tobacco brands, is responsible for the deaths of around five and half million people every year (World Health Organization, 2009). How can BAT provide anything other than lip service to social responsibility, while it manufactures and markets (in some jurisdictions) a toxic product? This is likely to be an example of where social responsibility is used for public relations and advertisement in an attempt to balance the good with the bad. Yet BAT provides a product to which millions demand (and are addicted to). The Friedman view would suggest that BAT is 
ethical as it engaged in an activity which is not only legally sanctioned, but is also beneficial to society through its utility in satisfying social needs (demand for tobacco) (Friedman, 1970; Hurn, 2008). But the fact that BAT ranks highly on some social responsibility scales seems to suggest an organisation can offset its morally reprehensible activities by ensuring that its moral ones are well advertised. This seems strangely familiar; it is similar to how a heavy polluter can offset their carbon emissions through purchasing carbon credits or paying taxes. However, corporations who actually break the law or act unethically risk a public backlash and even possible regulation and tobacco is one area which is closely and constantly regulated (Carrigan \& Atalla, 2001; Campbell, 2007; Goodpaster, 1991).

When businesses behave in unethical or criminal ways, trust in business falls and government regulation can follow sharply. During the financial crisis of 2008, public confidence in business shattered (Quelch \& Jocz, 2009; The Economist, 2009; Abate, 2009). There are multiple reasons for the credit crunch, but a significant cause was the short sighted behaviour of lenders who put money into the hands of subprime debtors (Alexander, 2009). The fallout from this was the collapse or bailouts of institutions such as Northern Rock in Britain in late 2007, and Lehmen Brothers, Bears Stearns, Meryl Lynch, American International Group (AIG), Royal Bank of Scotland (RBS), Freddie Mac and Fannie Mae (etc) in 2008. Like the Enron and Arthur Anderson collapses before them, the latest wave of collapses has caused significant distrust in corporate governance. In addition to this, corporate managers were receiving enormous payouts as tax payers rescued their over-exposed corporations. The public outcry and United States' President Barrack Obama's criticism against bonuses to AIG executives in the 'financial products' division (AIG required a government bailout) resulted in proposed legislation that would tax the bonuses at $90 \%$ (this was abandoned when employees promised to pay bonuses back) (Cho \& Brady, 2009). In the United Kingdom, controversy was sparked after Sir Fred Goodwin departed RBS with an annual pension entitlement of around $£ 703,000$ (Flanagan, 2009). This was after RBS required a government bailout after a $£ 24$ billion loss (Treanor \& Wintour, 2009). Despite this record loss and subsequent departure, Goodwin refused to give up the pension. The furore even caused an attack on Goodwin's house (Wade, 2009). While the behaviour that caused the credit crisis may have been a result of cavalier and short sighted lending, the crisis itself exposed one of the greatest frauds in history: Bernie Madoff and his ponzi scheme worth (US) $\$ 50$ billion (BBC, 2009). It has been a bad time for business.

This section has discussed corporate mismanagement and how it has affected trust in business and how this trend of social responsibility has emerged. But the responsibilities of business are yet to be addressed. Prior to this exploration into business ethics, stakeholder theory was discussed. The literature on stakeholder theory suggested that organisations need to pay 
attention to the interests of individuals and groups who are not only directly and indirectly affected by the business' actions but are also able to affect the business' ability to achieve its goals. There are numerous views of stakeholder theory but certain commentators and businessmen have extended this idea to suggest that the traditional role of business is no longer enough and that businesses owe a social responsibility to society (and stakeholders) (Bird, Hall, Momente, \& Reggiani, 2007; Hubbard, 1999). These views are also reflective of personal views of ethics and the role of business in society. The next section looks at the role of business in society through the context of social responsibility.

\section{Corporate Social Responsibility}

Recent advertising in the Economist magazine states that: "Oil Companies should put their profits to good use", that "Oil companies should support the communities they are part of", that "fighting aids should be part of corporate policy" and that "oil companies should support small business" (Chevron, 2011). However, these are not the advertisements of an NGO, but of Chevron, a major oil company. The statements (originally stated by various activists) are followed by a little red stamp stating "we agree". The advertising suggests that Chevron believes it has a social responsibility to support local communities, fight aids, support small businesses and put its profits to good use. But what does running an oil company have to do with fighting aids or supporting small businesses? Even if the activities were related, why publish multiple page-length advertisements? The likely answer is in the type of organisation Chevron is. Chevron is an oil company and given the enormous environmental damage caused by the BP gulf oil crisis in 2010, these advertisements are probably more about public image and perception than about any principled attempt to fight aids or put profits to good use. However, this example strikes at the heart of the CSR debate and one of the central research questions: what are the responsibilities of business?

Like the term 'stakeholder', CSR has multiple meanings. One definition of CSR is a company's commitment to minimising or eliminating any harmful effects and maximising its long run beneficial impact on society (Mohr, Webb, \& Harris, 2001). Alternatively CSR is offered as a construct which includes the economic, legal and ethical expectations society has of corporates (Montiel, 2008). Barnett defines CSR as "an action which appears to further some social good, beyond the necessary interests of the firm and that which is required by law" (2007, p. 796). This is perhaps the meaning Chevron adopts. An alternative definition is also offered by Barnett where social welfare is used as an instrument to enhance stakeholder relationships (Barnett, 2007). Elbing's definition of social responsibility sees social responsibility as something beyond the traditional managerial pursuit of profit maximisation Elbing, (1970) cited in (Montiel, 2008). 
Davis (1973) suggests that social responsibility starts when legal obligations end, meaning an organisation is not socially responsible if all it does is comply with the law. Davis justifies his statement by saying that this is what any good citizen would do. There are numerous writers who criticise such an approach as imposing obligations upon business (Goodpaster, 1991; Friedman, 1970; Barry N. , 1999; Kerr R. , 2004; Kerr R. , 1998; Carroll, 1979). Interestingly, research has indicated that consumers support businesses that obey the law and meet their individual needs, but do not support businesses that deliberately go beyond minimum expectations (Bird, Hall, Momente, \& Reggiani, 2007). It is not clear why this is, but it may be because consumers do not think businesses should be engaging in social activities or think it is just advertising. Another definition of CSR offers a tighter and more conservative definition of CSR. It is where as an organisation avoids causing harm to its stakeholders and where harm occurs, takes responsibility for fixing it (Campbell, 2007). This would suggest that CSR means something like minimal legal standards and duty of care toward stakeholders. Johnson (1971), cited in (Carrol, 1999) presents four different definitions centred around either a stakeholder approach, profit maximisation, multiple goals (beyond profit maximisation) and a definition where social responsibility is dependent upon profitability. Carroll outlines a definition of social responsibility that includes the economic, legal, ethical and discretionary sides to business performance (1979). To elaborate, the economic responsibilities relate to important role of business as a wealth generating utility, legal responsibilities set a social contract in which the business must operate, ethical responsibilities are un-codified behaviours by which an organisation is expected to comply by and finally, discretionary responsibilities are those left to the judgement of the organisation, such as charitable contributions (Carroll, 1979).

The above definitions range from where the social responsibility of a business is to minimise harm, to the satisfaction of societal expectations, to definitions where social responsibility requires a positive action beyond the interests of the organisation. CSR seems to mean many different things. There are interpretations of CSR which include, profit making, voluntary activities, legal liability, ethical behaviour, charitable contributions, a duty to stakeholders or a search for organisational legitimacy (Votaw, 1973; Carroll, 1979). Montiel's research states that the use of the word CSR has lost ground, in articles published, to the newer term 'corporate social performance "CSP" (2008). Barnett also refers to the increased use of the term in business and society literature (Barnett, 2007). CSP can be understood as the overall performance of a business' CSR policies, programs and social responsiveness at a given point in time (Barnett, 2007; Montiel, 2008).

The definitions of CSR and the activities in which a business engages itself seem to be indicative of personal beliefs and world views. In other words, the action a business takes will be 
reflective of how the business sees its role in society. CSR is also likely to mean different things in different periods of time as expectations for social responsibility can be triggered by sudden events (Chinese melamine milk crisis, global warming etc.). Social responsibility is best treated as a very liquid concept (Campbell, 2007). In addition, Smith and Ward comment that the future of business could move toward a situation where the fiduciary duty to shareholders is be balanced with other stakeholders (2007). On page 20 of their article the same authors offer an alternative future where there is a movement away from "shareholder capitalism to a radically different enterprise model in which social purpose is placed above profit or profit is harnessed to social purpose". However, this does seem unlikely in adoption in a society composed of selfinterested individuals. In any case, corporate attitudes remain centred around shareholder capitalism but are beginning to accept the importance of how social and environmental issues can affect corporate performance (Zairi \& Peters, 2002).

Social issues that currently face businesses include environmental and climate change concerns, supply chain issues and community investment (Welford, 2008). The environmental concerns are an obvious issue, less so is the institutionalisation of CSR. The international organisation for standardization (ISO) has developed ISO26000, a standard that gives guidance on social responsibility (International Organization for Standardization, 2008). Adoption of ISO 26000 is of course voluntary and is created for public and private institutions alike. The new standard is being developed by leaders in social responsibility and aims to provide a definition of social responsibility. However, because the ISO is voluntary, and the financial benefits of CSR are not proven, it will be interesting to see how organisations and consumers respond to the new standard, if they do at all (Aupperle, Carroll, \& Hatfield, 1985; Burke \& Logsdon, 1996).

Rather than trying to define or understand more about the responsibilities of business, much of the existing literature in the field of CSR has tried to establish a relationship between a corporation's social responsibility and its financial performance (Bowman \& Haire, 1975; Parket \& Eibert, 1975; McGuire, Sudgren, \& Schnessweis, 1988; Burke \& Logsdon, 1996; Vogel, 1991; Aupperle, Carroll, \& Hatfield, 1985). However, the link between corporate altruism and profit remains elusive. Numerous studies over the course of over 30 years have produced a consistent outcome where the only consensus is a lack of consensus (Barnett, 2007). Research on financial performance and CSR has even been dismissed by some researchers as research in search of a theory (Ullman, 1985). CSR is incredibly difficult to quantify in terms of its effect upon financial performance because any benefits are indirect and financial performance itself is based on many independent variables (Husted \& Allen, 2007; Aupperle, Carroll, \& Hatfield, 1985). The lack of definite outcomes from the CSR-CSP research has resulted in a study analysing articles that claimed or dismissed the relationship between CSR and CSP (or articles 
that claimed there was a neutral link. One study found that there were thirty-three studies that claimed a positive correlation between CSR and CSP, five that claimed a negative relationship and fourteen that claimed there was no relationship (Roman, Hayibor, \& Agle, 1999). The reason behind the inconsistency and lack of conclusive findings is thought to be poor conceptual frameworks, an insufficient sample size and poor methodology (Bird, Hall, Momente, \& Reggiani, 2007; Aupperle, Carroll, \& Hatfield, 1985). In practical terms, corporate financial performance will only increase as a result of CSR if there is an increase in revenue or a decrease in costs accruing from the CSR activities (Barnett, 2007). These increases in revenue or decreases in costs are going to be hard to trace, but a framework has been suggested whereby CSR activities increases trust with stakeholders resulting in lower transaction costs and investment opportunities with these stakeholders (Barnett, 2007). The argument is that CSR initiatives which do not serve the utility of lowering costs or increasing revenue should be avoided.

Research in CSR has focused on trying to prove that there is a positive link between CSR and CSP (or any link for that matter). However, there seems to be too many variables at play for any meaningful conclusion to be drawn between financial performance and CSR. Despite this, other inferences can be made from the relationship. For example, it is generally accepted that organisations engaging in negative behaviour will suffer in terms of market valuation (Bird, Hall, Momente, \& Reggiani, 2007). Campbell (2007) notes another aspect of the relationship between CSR and CSP that indicates that there is a positive relationship between an improvement in an organisation's financial position and a subsequent increase in CSR. The implication of this is that businesses are expected to be more altruistic or more engaged in social responsibility when they are in a better financial position. This may be because profitable businesses are able to afford CSR programs. But what about in the contrary situation; where corporate performance decreases? Will organisations spend less on CSR? Since we have had one of the biggest periods of economic decline since the 1930s, what effect has the recession had on attitudes toward CSR and could unprofitable businesses disregard CSR or act in an unethical manner because they simply cannot afford to be socially responsible? The answer to such a question would clarify whether social responsibility is a voluntary or compulsory part of business. The existing research does not cover this. However, there is existing research on corporate behaviour in a declining business. Lemke \& Schminke created a study using MBA students to understand the behaviours that result in unethical activities in declining businesses (1991). The study found that organisations facing decline were more likely to engage in behaviour that is unethical. Questionable activities are more and more palatable as decline sets in (Lemke \& Schminke, 1991). This of course may extend to a context such as the recession. The slack resource theory has a similar theme; it suggests that organisations which are in a weak position 
are not as likely to engage in socially beneficial behaviour (Campbell, 2007). Indeed, in line with Lemke and Schminke's findings, organisations are less likely to meet minimal ethical standards when they are struggling (1991). But the question still stands about what we expect from businesses and whether a recession changes attitudes about what the responsibilities of business are.

There are fundamental problems with CSR beyond the ability to make a connection with profit. The first problem is that research suggests that most people do not know which firms are socially responsible. For example, little more than $33 \%$ of the British public can name a company that engages in social responsibility, while only $30 \%$ can name a company perceived to be environmental, socially responsible or ethical (Dawkins, 2004). This presents a difficult situation for a business: if its CSR activities are promoted then it risks being accused of paying lip service to CSR, if it does not promote them then it risks being accused of not contributing or being socially responsible (Alsop, 2002). Alsop refers to the aftermath of September 11, where companies like Johnson and Johnson and Honda donated millions in aid and products without promotion of their contributions (2002). Johnson and Johnson, as well as Honda, were subsequently accused of doing nothing to help. In some cases a business cannot win. On the other hand, too much promotion is perceived by some consumers as profiteering. In a survey cited by Alsop, half of the respondents thought press releases were a suitable way to promote CSR activities while 40\% recommended using annual reports and websites for the information. One writer notes that "socially responsible corporate behaviour may mean different things in different places to different people and at different times, so we must be careful in how we use the concept and how we define it" (Campbell, 2007, p. 950). Consumers have also placed businesses under pressure for being too profitable; there seems to be a presumption highly profitable business is not being socially responsible. This is the paradox of performance. It is where a corporation's financial performance is so strong that any social responsibility will be seen as too little (Barnett, 2007). The paradox of performance seems to indicate that socially responsible firms can only be mildly successful. The perception of 'excessive profit' also ties back into the previous section about lingering religion values on the morality of business, selfinterest and profit. The second problem is that people are sceptical about why a business would engage in CSR. Alsop (2002) argues that American consumers are sceptical about corporate philanthropy because they think that businesses are motivated only by self-interest and that CSR is usually accompanied by promotion. Campbell states that consumers think negatively of businesses who embrace CSR for the purposes of branding or marketing (2007). These businesses risk punishment by consumers (Bielak, Bonini, \& Oppenheim, 2007). 
It seems that CSR can be a 'catch 22' for business (they risk criticism if they advertise their CSR and criticism if they do not engage in CSR). So why do businesses engage in CSR? Campbell suggests that an organisation's behaviour is a portrayal of the context in which it operates (Campbell, 2007). Managers have a significant impact on the social responsibility of a business. This means that businesses are more likely to be socially responsible when their managers belong to professional groups, organisations or institutions (Campbell, 2007). They are also likely to be influenced by business publications, conferences and university courses which condone or promote social responsibility (ibid). Managers can also influence CSR standards by being competitive about their CSR activities. An increase in CSR is likely to cause competitors to increase their CSR activities. Businesses can further establish a competitive strategy by lobbying for higher standards which would place the business at a competitive advantage (McWilliams, Van Fleet, \& Cory, 2002). Businesses typically respond to social issues reactively, defensively, minimally or proactively (Carroll, 1979). The reaction by a business to social issues is called 'social responsiveness'. Businesses which are proactive can set social issues without being stuck defending their positions (Carroll, 1979). This is an important lesson for managers, who need to do more than merely react; they need to set the agenda for CSR. If an agenda is set then rules can be set which can change the environment so that social factors favouring the organisation are part of consumer choice (Smith \& Ward, 2007). This proactive approach can also be achieved (and negative publicity avoided) where a business proactively and strategically aligns its operations with a social cause.

There is also a growing movement from philanthropic based CSR to strategic CSR which is based on investment in the community which is closely tied to a business' strategy (Welford, 2008). The core of this argument is not that businesses have responsibilities, but that businesses should make the most out of the call for CSR by investing in causes that will bring benefit to the business as well as society. In fact, Porter and Kramer write that businesses engaging in CSR should be guided by whether shared value can be created between the business and the social cause (2006). Porter and Kramer suggest that attention needs to be focused on social issues which cause the company to be competitive in the place it operates as well as social issues which affect or are affected by the business' value chain (Porter \& Kramer, 2006). However, many businesses engage in CSR that is unconnected to business strategy. This means that businesses miss the chance to cause greater social progress through the direct application of their expertise and knowledge (Porter \& Kramer, 2006). Current practices have been called a "hodgepodge of uncoordinated CSR and philanthropic activities disconnected from the company's strategy that neither make any meaningful social impact nor strengthen the business' long term competitiveness" (Porter \& Kramer, 2006, p. 83). If a business applies its resources, knowledge and talent to social problems it has an interest in, then there is enormous 
potential for positive social impact (Porter \& Kramer, 2006). Burke and Logsdon argue that a business' involvement in CSR should be based on the strategic fit between the CSR activity and the potential returns to the business (1996).

Porter and Kramer also argue that the closer a business' services or products are tied to a social issue, then the greater the opportunity for the business to use its resources to effect change (2006). In addition, the authors state that less attention should be given to generic social issues (ibid). CSR activities should be based on the strategic context of the organisation. This means that the strategy should be unique and in a way that lowers cost or serves a particular set of needs. In a survey of CEOs conducted by the McKinsey Quarterly, $90 \%$ of respondents said they have tried to incorporate social issues, including the environment, into core strategy (Bielak, Bonini, \& Oppenheim, 2007). Dawkins suggests that CSR needs to be relevant to consumers and can be made relevant by showing how CSR fits into the business' strategy (2004). The challenge for corporations is to engage in CSR that fits their brand and culture (ibid). CSR is strategic when it supports the core business activities of a business. For instance, if an organisation is interested in improving employee relations it should engage in CSR that will improve employee relations. Porter and Kramer along with Burke and Logsdon and Barnett make the idea of instrumental stakeholder theory, which argues that CSR contributes to the bottom line through favourable influence with important stakeholders, even more strategic (Barnett, 2007). But is this movement towards strategic CSR simply another way of maximising profit (which makes it instrumental)? If the CSR and philanthropic contributions made to society are another way of maximising profit, how should people feel about receiving corporate donations?

There are a variety of definitions, interpretations and applications of CSR that have been discussed in this literature review. This section has also discussed the concept of strategic CSR and how businesses can tie CSR into their business activities. In addition to this, this section addressed how much of the existing research on CSR has focused on proving a relationship between profit and CSR activities. However, there is also a notable gap in the literature that explores social responsibilities in a macro-economic context or national crisis such as the 2008 financial crisis and recession. In the initial period of writing this literature review, which was at the start of 2009, there was little or no research on corporate social responsibility and the recession. As at the start of 2011, literature is slowly starting to emerge, but it is mostly of poor quality and contains no original research, but instead list observations or thoughts on CSR based on news articles. The aim of this research is to address this gap. The following section begins this process by exploring the impact of the recession and financial crisis. 


\section{The Recession and the Financial Crisis}

In a clear reference to the great depression, the recent recession has been named the great recession (Gibbs, 2009). The great depression was, of course, a period of great economic decline and destabilisation where $25-30 \%$ of the workforce in America was unemployed (Kato, 2009). The recent recession seems to have had a significant impact on most developed and some developing countries and is the most significant recession since the great depression in the 1930s (Schmitt \& Baker, 2008). In New Zealand, the recession has not been as disruptive as it is has been overseas largely because of New Zealand's isolation from the some of the circumstances that caused the credit crunch and that are still ravaging the United States and much of Western Europe (though it is important to note that New Zealand was in recession before the 'crunch' of the credit crunch). However unemployment has almost doubled from about $3.5 \%$ before the credit crunch to around $6.8 \%$ at the start of 2011 . In terms of the affect on GDP, it has been a long but shallow recession where GDP declined from the December 2008 quarter to the second quarter of 2010 and declined once again in the 2010 December quarter (Statistics New Zealand, 2011). In contrast, countries like the United States, Britain and Germany experienced significant falls in GDP and increases in the unemployment rate in the immediate after math of the recession (The Economist, 2009). With the exception of Britain, these countries have returned to economic growth while the unemployment rate has remained stable in the USA, increased in Britain and decreased in Germany (The Economist, 2011).

One of the most interesting elements of a recession is its impact on consumer spending. Consumers need to have disposable income, feel confident about their future, have trust in business and embrace consumption to be confident and engage in purchasing (Quelch \& Jocz, 2009). However, bad economic news undermines this. The effect of the recession may have altered consumer behaviour in countries with high consumer debt, where consumers have lived beyond their means (Quelch \& Jocz, 2009). The result is that consumers have been spending less and saving more. The deeper a recession is, the longer it takes for consumer behaviour to return to normal, the sense of vulnerability can last for decades and even generations (Kato, 2009). Quelch and Jocz (2009) identify four groups of consumers that emerged during the recession. The first is the slam on the brakes group, who is hit the worst by the recession and will respond by cutting purchases. The second group is what Quelch and Jocz call the Pained but Patient, they are likely to also respond by cutting purchases, but not by as much as the first group. The third is comfortably well-off consumers who are feel secure and consume and almost the same level irrespective of the recession but are more careful about what they buy. The final group is the Live for Today group where there is no change in behaviour (Quelch \& Jocz, 2009). 
A recession usually changes consumer focus to essential products or discounted products while luxury goods fall in sales (Quelch \& Jocz, 2009; Kato, 2009). Sales of value-brand essential products are likely to climb during this recession (Quelch \& Jocz, 2009). Consumer behaviour should result in an increase in savings rates and a corresponding fall in spending. If this condition becomes widespread then we come across the concept of the paradox of thrift and deflation. The paradox of thrift is where widespread negative news about the economy lowers consumer confidence causing consumers to delay purchases. This delay of purchases causes demand to drop and as a result, employees to be laid off further lowering consumer confidence (Kerr W. , 2009). This behavior results in a vicious recessionary spiral. The paradox of thrift presents a real threat to economies considering that consumer spending usually makes up $75 \%$ of GDP (Kerr W. , 2009). The value of business stocks and house prices which once made people feel wealthy, have dived (and in some places are continuing to) engendering a deep sense of vulnerability. This has resulted in what the economist magazine called the desire to live within one's means and a "backlash against bling". (Quelch \& Jocz, 2009; The Economist, 2009). Time Magazine reported that a majority of American respondents to their money spending survey are likely to change their long term spending habits and spend less as a result of the recession (Gibbs, 2009). An interesting article in the Washington Post by Michael Rosenwald claimed that well off consumers have fallen into a psychological trap of frugality, where it has become fashionable to spend less. This abstinence from spending has caused enormous damage to the economy (Rosenwald, 2009).

The other side of the 2008 recession is how businesses treat CSR. There are claims that CSR budgets were one of the first things to be cut as they are usually perceived as a tool for public relations (Hernandez, 2009). While an article in The Economist does confirm that CSR budgets have been cut, the article also states that the focus of these cuts has been on CSR expenditure peripheral to the organisation, such as philanthropy. This has resulted in businesses focusing on issues that are more relevant to it (The Economist, 2009). The article also suggests that the recession has had a serendipitous effect, causing businesses to treat CSR strategically (The Economist, 2009). But should businesses be expected to be philanthropic in hard times? In another article from the Washington Post, Flavelle (2009) asks, "at a time when so many American companies are unable to generate a profit and many more are forced to lay off workers, is it reasonable to ask those companies to devote their energy toward anything other than the bottom line? Is it good for them if they do?" This raises an interesting point: do our expectations of business change during a challenging period such as a recession or are expectations of CSR conditional on the economic environment. It also raises other questions: do businesses have more social responsibility toward their customers or employees during a recession? These questions lead to a central question of: what is the role and responsibility of 
business in a recession? And if the recession does change the business responsibilities then it must also influence the role of business or at least inform the debate on business and society.

\section{Conclusion}

The 2008 financial crisis almost caused the collapse of the global financial system. The exposure of many huge investment banks to subprime lending caused some to collapse and national governments to intervene to save others. In New Zealand, our major banks were not as exposed to subprime mortgages but, like other countries, were vulnerable to the decline in global lending. This had the potential to shut down numerous businesses which relied on financing from banks. Bank of New Zealand (BNZ) a major New Zealand bank continued to lend to businesses during this period where other banks did not. This financing ensured the survival of many small businesses (Bank of New Zealand, 2011). However, it is not clear whether such situations are motivated by a desire to take business from competitors, to gain favourable promotion or whether the motivation was social responsibility. And if it was social responsibility, did the bank feel compelled to be social responsible because of the recession and whether the bank felt compelled to be socially responsible because of the recession? These are the issues which make the debate on the role and responsibilities of business so interesting.

This chapter has reviewed a wide variety of literature. The literature review started with an exploration on the role of business and the debates arguing for businesses to have a purpose beyond generating money. The review then moved onto a discussion on what businesses were responsible for and the various meanings of CSR. This review has demonstrated that CSR and business responsibility take many different forms including philanthropy and social contributions but that there is a large debate about the role and responsibilities of business and whether business responsibilities are mandatory, voluntary or strategic. However, this literature review has identified that there is little existing research or understanding on how factors such as economic context and profit influence what responsibilities people think a business has. The 2008 financial crisis and recession provides a perfect opportunity to understand more about what drives the role and responsibilities of business. Based on these gaps, this research seeks to answer the following questions:

1. What is the role of business in society from the perspective of consumers, policy managers and business managers?

2. What are the responsibilities of business in society from the perspective of consumers, policy managers and business managers?

3. Does economic context influence the role or responsibilities of business? 
The answers to these questions will provide a greater understanding about social responsibilities and the role of business. The following chapter details the methodology for how these questions will be answered. 


\section{Methodology}

\section{Chapter Aims and Overview}

The purpose of this chapter is to describe the purpose of the research, the research philosophy, ethical considerations, data collection method, data analysis method and briefly discusses the limitations of the methodology. This chapter also provides the justifications for the data collection and data analysis methods.

\section{Research Purpose}

The purpose of this research is to understand more about the role and responsibilities of business in society through the context of the recession and financial crisis. The recession is used as a lens or context by which this relationship can be understood. This research is important for three reasons; the first is because there is an ongoing debate into what businesses are responsible for. The second reason is because there is little or no literature on what influence economic context, or context generally, has on business responsibilities. The third reason is that this research will provide guidance to businesses on how to manage their 'responsibilities'. This purpose has yielded three core research questions:

1. What is the role of business in society from the perspective of consumers, government policy managers and business managers?

2. What are the responsibilities of business in society from the perspective of consumers, government policy managers and business managers?

3. Does economic context influence the role or responsibilities of business?

The first question seeks to understand more about what the role of business by exploring what the purpose of business is. The second question explores not the purpose of business, but the range of actions or responsibilities a business is accountable for. These questions relate strongly to the literature review and establish the background for the third question, which addresses economic context and looks at whether factors such as economic context influence the role or responsibilities of business. The answer to this will provide a greater understanding about social responsibility and what society expects from business. 


\section{Audience}

This research is intended for multiple audiences. These are the academic, business and other interest group audiences. The academic audience will be interested in this research because it seeks to contribute to the literature on business and society by exploring the debate on business responsibilities and offering a greater understanding to what social responsibilities a business has. The business audience will be interested in this research for its practical contribution in removing some of the ambiguity about how businesses should engage with stakeholders and which CSR programs (if any) they should involve themselves in. The final audience is the special interest groups, who will be interested in this research because they either agree or disagree with the findings and its possible influence on theory and business practice.

\section{Research Philosophy}

This research is located within the functionalist paradigm. The functionalist paradigm is concerned with the maintenance of the status quo and examines relationships that result in generalisations and universal principles (Gioia \& Pitre, 1990). Management research in this paradigm would typically involve reviewing existing literature and then developing a hypothesis for development of theories or the search for a gap in knowledge. This would follow with the collection of data according to hypothesis. The data collected would then be examined quantitatively in order to verify, or prove false, the hypothesis (ibid).

The philosophical stance of this research is that there is an answer to the role and responsibilities of business and the purpose of this research is to offer an answer for what this could be, based on the exploration of participant responses and themes. The research questions have been designed to "provide essentially rational explanations of social affairs" (Burrell \& Morgan, 1979, p.26). However, my research deviates from the quantitative methodologies of functionalist research because it adopts a qualitative data collection method and data analysis method. The justification for the selection of these particular methods is provided further in this chapter. But it is important to note that rather than trying to represent the truth or the single answer to the role of business in society, which would be difficult given the limitations of a qualitative methodology, this research aims to offer an answer to a societal issue despite the subjectivity involved in qualitative research methods. 


\section{Ethical Considerations}

The data collection for this research involved the participation of a number of people from corporate, government and private backgrounds. The involvement was in the form of a one-toone semi structured interview. There were a number of ethical considerations for this research. The first consideration was to ensure the confidentiality of participants while the second consideration was to be careful about representing myself as a researcher and an employee of an organisation which was not a party to the research. The third consideration was how participants wanted to represent themselves.

I told the participants that their privacy would be maintained and that no identifying information would be published. I was bound to these terms through the conditions of participant research. I also assured that participants that the interviews and results would be treated confidentiality and all identifying documentation (save consent forms) have been destroyed. Also, all participants have been given generic labels in the body of this paper, for example: consumer one or government two, for example. Given the status of some of the participants, and the opportunity for mischief to occur if any of the data was to be misplaced, I have taken the issue of confidentiality very seriously.

The second ethical consideration was that I would be conducting research while I was also an employee of a non participating organisation. In addition, the practicalities of interviewing government policy makers and business managers meant most interviews would be conducted during work hours at my employer's premises or the participant's workplace. I spoke to my employers about how this could be managed. We agreed that all Business and Government interviews could be conducted during work hours, but that consumer interviews would need to be taken in my own time. In addition, I was to make it clear this was a piece of academic work and that I was to do nothing which would imply that my employer was involved in my research.

The third consideration was how the participants represented themselves. Many participants were only willing to speak on the condition of anonymity. Many were also only prepared to speak as long as their views were not attributable in any way toward their organisation. The participants were also assured that information would be collected from the perspective of a person in their role, rather than as a representative of their business. Because of the involvement of external parties and the potential ethical issues above, ethical approval was sought to allow the research to be undertaken under the University's name. In late 2009 the Victoria University of Wellington Human Ethics Committee granted ethical approval for carrying out the data collection under the University's name. 


\section{Data Collection}

\section{Data Collection Method}

My ambition was to collect both quantitative and qualitative data. The quantitative research would have been in the form of a survey whereby a large number of participants would be asked to complete the survey. This would then be followed with interviews of a smaller number of participants. However, I decided that interviews would provide the most interesting set of data and that a single data collection method was appropriate for the size of this thesis.

Interviews were the method of data collection for this research. The interviews were formal oneon-one, face-to-face, semi-structured interviews. One of the questions that I have frequently encountered when discussing my thesis with other students is why I chose interviews ahead of surveys. This kind of question is usually an implication that surveys are a more scientific or objective method of data collection compared to interviews. While it is true that surveys provide an efficient way of gathering answers that can also be quickly aggregated, I have always been sceptical of survey based research. This is because of my own experience of losing interest in surveys, becoming frustrated at poorly written questions or choosing a random response. These surveys are then subjected to analysis and, unknown to the researcher, the results risk becoming an aggregated form of a sample size's recklessness. Although this is not true of all surveys (or participants), interviews are a superior method of getting and exploring (or digging into) a participant's response (why and what rather than just what), which is the problem with quantitative data (O'Leary, 2004; Cassell, Symon, Buehring, \& Johnson, 2006; Mayan, 2001). However, interviews are of course subject to interference from the researcher and the interviewee may feel like they have to give answers that impress the interviewer rather than answering forthrightly (ibid). Surveys avoid this and they also have the benefit of drawing a relationship between variables to be drawn and being scientifically true. However, the purpose of this research is to understand more and to draw lessons from the data. For the purposes of this research, interviews, a qualitative data collection method, have been selected as the most appropriate method.

The interviews were formal because the formal nature of the interviews gave them a greater sense of seriousness. This was important because I was using the work time of Business Managers and Policy Managers who would be frustrated with an informal interview. For all interviews I, along with my policy and business participants, was dressed in business clothing. This also made the interviews seem more formal. For consumer participants, the interviews took 
place across the week and the weekend. There was no particular place the interview was held, just a variety of settings where consumers could be recruited for participation.

The interviews for all participants were semi-structured. The purpose of this was to ensure consistent coverage of the questions amongst interviewees (O'Leary, 2004). However, the semistructured nature of the interviews allowed me to explore interesting answers and thoughts the interviewees had, or to drive down deeper into their answers in order to get a richer understanding of their responses. The interviews were typically 30-45 minutes long and were held in a variety of settings. Most interviews were held at my workplace while others were held at the participant's workplace. The variation in setting was made to suit to the participant.

At the start of each interview, a summary of the purpose of the research was given to the participant along with an opportunity to ask any questions. The consent form was then handed to the participant and they were given time to read the information sheet, sign the consent form and ask any further questions. All but one of the interviews was recorded. The purpose of these recordings was to allow further analysis and coding of the interview. The participant who declined to be recorded was uncomfortable about this, so the interview proceeded without being recorded. This participant was the only one not recorded. Although this impacted on the amount of information collected (and the subsequent analysis) compared to other participants, I decided to proceed with the interview by taking detailed notes. All of the interviews were undertaken without any prior research into the participants or their organisations. This was to ensure that I could not give any information that could prompt an answer out of them or select participants who would give favorable answers.

\section{Research Design}

As the purpose of this research is to understand more about business responsibilities through the context of the recession, the interviews and participant types were designed to support this purpose.

The three participant groups involved in this research represent what I considered to be the three most important stakeholders in the business and society literature: the consumer, who buys from businesses, businesses who sell to consumers and policy makers who set or influence the boundaries of the consumer and business relationship. These participants are directly relevant to the research question. I considered that the equal involvement of all three participants would be the best way to gather meaningful data. Criteria were established for each participant group. A business participant was someone working for a business in a managerial 
position. A policy participant was someone at either managerial level (or who had policy expertise), working in a government department or an interest group with an expertise in either the management of the economy and business or consumer regulation. These areas of expertise were important because I needed Policy managers who had knowledge on the subject area (for example, it would be pointless asking a criminal justice or defence policy manager to participate in this research). The positions of the policy and business participants needed to be at managerial level such that they would understand the way their business operates (by being exposed to or participating in important decisions). The criteria for consumers were the widest: anyone who purchased and was not involved already involved in the research as a policy or business participant.

The interviews consisted of three parts. The first part explored, without specific context, what the role of business was and whether businesses had any responsibilities and what these would be. This related closely to the first and second research questions. The second section tries to understand what participants think the impact of environmental context (such as the recession) has on a business' responsibilities. This related to the third research question. The final section compares business factors such as profitability with environmental factors such as economic context, the purpose of this section is to understand more about the economic context and business responsibility and to understand what other business factors could influence responsibility. This section also related to the third research question. The limitation of this part of the design is between the first and second sections; the participants were interviewed during the recession. This means that the recession was already considered in their answers because it was the status quo. This was a possible limitation, but I was careful to frame the interview questions appropriately or to guide the interviewee to the appropriate context. The interview question sheets can be found in the appendix $\mathrm{c}$.

The interview questions were varied between the participant groups. This was because each participant group was considering the questions from a slightly different perspective. The variation in consumer interviews was to account for the purchasing behaviour of consumers, while the questions for business and policy interviews were very similar to each other. It is worth noting that while all participants were asked the designated questions, the interviews were semi structured. This allowed interesting points or answers to be explored.

\section{Participant Recruitment}

The data for this research was collected through twenty-one interviews. These twenty-one interviews which were split into three participant groups: Business Managers, Policy makers and 
consumers. There were seven participants from each group. The sample size was twenty-one because it was a sensible and achievable number of interviews, given the scope and size of this research. All the interviews were completed in Wellington, New Zealand. The interviews were completed here because of the ready availability of a mixture of business participants and policy participants (since Wellington, being the capital city, has almost all policy managers based there) as well as a variety of consumers.

Each participant was asked to participate not as a representative of their organisation, but based on their experiences in their roles. This was to ensure the involvement of the participant as many participants were only willing to be involved on the basis that their views were not attributable to their organisation. Despite agreeing to this, some prospective participants refused to participate, one stated that since she advised the government her views could not possibly be distinguished from government policy. This was disappointing as I stressed the views were not to be representative of her department. One advantage of this approach, which was successful with other participants, was that they could speak their mind based on their experiences or impressions without being an agent for their workplace (since they would not be identifiable). Another advantage of this approach was avoiding the public relations responses I encountered in previous research where representatives from marketing or public relations were the participants. The responses were usually guarded and made to make the business look better. For this reason, I targeted participants (for Business and Policy) who were in operational or managerial roles and who I thought would not engage in a public relations exercise with me.

When I was recruiting participants, I was also conscious of the fact that policy and business participants could easily confuse their roles with consumers. This was because all business and policy participants were also consumers. I took care to ensure that the participants answered in their role as a policy or business manager. In spite of this, I noticed that some participants would suddenly start talking about their purchasing behaviour as consumers. When this occurred I listened to their response and then directed the question back to a business or policy context.

\section{Data Analysis}

After collecting the data, the first step of the data analysis was to transcribe each interview. This was done personally. After the interviews were transcribed, they were examined closely (coded) for themes. Themes were taken from both a local perspective (each individual interview) and a global perspective (the general themes from the interviews). The latter was completed through a compilation of key words, expressions and phrases. These were placed on large computer 
generated tables where both local and global themes could be explored. From this, the results section was written.

Coding was the considered the most appropriate data analysis method because interviews were the data collection method. Coding is where the collected data is analysed for themes (O'Leary, 2004). However, coding is criticised because the researcher can passively or actively 'focus' on themes which are relevant or favourable to the researcher's outcomes (ibid). Basically, the researcher influences the results. Statistical analysis, in contrast, has the obvious benefit of having a mathematical truth (the researcher's analysis method has little impact on the results) (ibid). However, the purpose of this paper is not to represent the relationship between variables but rather explanations to understand social situations. Given the data collection method and the desired outcomes coding was the appropriate data analysis tool.

\section{Limitations}

One of the most significant limitations of this methodology is that there was a limited sample size and all data was collected in Wellington, New Zealand. As stated above, the sample size was modest to ensure completion of this research and the location of the research may have some impact on its findings. This is because Wellington is a wealthier and more educated area than many parts of New Zealand (Wellington, 2009). The findings may have been different in smaller or poorer parts of the country where poorer or less educated participants may have had completely different expectations of businesses. However this is presumptive as I do not know where the participants came from and wealth and education may have little relationship with a favourable attitude towards business.

Another potential limitation of this methodology is that it has an objective purpose despite using subjective/qualitative research methodologies to answer the research questions. This limitation means that the results cannot be claimed to be objective or to be the answer to a particular social problem. In addition, people who are quantitatively inclined may claim that because the data collection methodologies are subjective that the findings cannot even be offered as a possible answer to the role of business in society. However, these interviews have provided a rich source of data which will contribute toward a greater understanding of the roles and responsibilities of business. 


\section{Conclusion}

This chapter has explained the purpose for this research along with the research perspective which attempts to balance an objective weltanschauung with a qualitative data collection and data analysis method. This chapter has also detailed why interviews were chosen as an appropriate data collection method, why coding was chosen as the analysis method and the reasons behind the participant groupings and the way in which participants were recruited. Finally, the limitations of this methodology were explained.

The following two chapters detail the results of data collection and analysis. The first results section addresses the first two research questions of: what is the role of business in society and what are the responsibilities of business in society. The second results section addresses the final research question which is: does economic context change the roles and responsibilities of business. 


\section{Data Analysis (1): The Responsible Business}

"The entity of a business isn't really moral; it is there to make profits and to respond to market signals (Policy Six)".

\section{Chapter Overview}

Twenty-one participants were interviewed with the aim to understand more about the role of business in society and what impact economic context has on society (the results of the latter will inform the former). The purpose of this chapter is to address the first and second research questions. The first research question is: what is the role of business in society from the perspective of consumers, policy managers and business managers? The second research question is: what are the responsibilities of business from the perspective of consumers, policy managers and business managers? These questions will be answered by describing the themes which were drawn from the interviews, followed by a discussion that ties the results back into business and society literature. This chapter is concerned with establishing the participants' understanding of what role business should play in society as well as establishing the expectations and demands of business. This chapter does not address how economic context influences this. This is covered in the following chapter. However, the discussion in this chapter is essential for providing a basis for comparing whether the roles and responsibilities of business change according to economic context.

This chapter begins by examining the purpose of business and what responsibilities participants expect from business. This chapter relates closely to the literature on stakeholder theory, CSR and the relationship between business and society. In the first section of the data analysis, the reason for the existence of a business is explored (the purpose of business) and then the minimum requirements of business are explored (the mandatory elements of responsibility). The following sections address the important but voluntary themes related to social responsibility, such as being customer oriented (satisfaction of customer needs) or strategically selfish (strategic self interest), avoiding any detrimental impact on stakeholders (mitigate harm) and finally, making society a better place for those around you (the extreme interpretations of social responsibility). A model then follows which summarises the findings and shows how different approaches to social responsibility compare with each other. The model and data analysis are followed by a discussion, which draws together the results to establish what participants think the role and responsibilities of business are. 


\section{The Purpose of Business}

"You have to start with the concept that business is an artificial construct, you are coming together for a given purpose, so you must be committed to that purpose in the first instance. If you do not achieve that purpose, you cannot continue to exist. You cannot let broader issues get in the way of your purpose" (Policy Seven).

The participants in this research were almost unanimous in stating that the purpose of business is to make money (or return wealth to shareholders). In addition, consumers said that the reason they would go into business would be to make money, while policy makers also thought that "most people go into business for the purpose of making money" (Policy One). The single exception to this consensus was the view of a business participant, an owner-operator, who stated that the reason he went into business was because he thought he had a point to prove. Money was secondary to his ego (but also incidental to it). Another business participant agreed that the purpose of business is to make money, but provided a slight variation in his view and stated that the purpose of his business, a bank, was to keep the wheels of business turning and to help the economy to continue to function (and profit would be achieved, in most instances, by doing this). Other variations of purpose also emerged, with consumers referring to satisfaction of customer needs and the return on investment as additional purposes for business. Policy and Business participants referred to business objectives and delivery of expectations, while one consumer summarised the set-up of our social and economic system as one of profit-making.

Societal norms are very different amongst people who are trying to maximise their return on other people's labour and to people who ask for their neighbours help. Our system is based on the idea that I will buy something from you for as cheap as possible and you want to sell it as high as possible and it clears at a satisfaction point (Policy One)

Although the purpose of business is to make money, rules or guiding principles are required to set the boundaries for the consumer and business relationship. The following section establishes what the participants considered were the minimum operating standards of a business.

\section{The Mandatory Elements of Responsibility}

The previous section established that participants thought businesses exist to make money, but what obligations or responsibilities do businesses have in their pursuit of profit? The participants all thought that businesses had an obligation to meet a minimal standard. All participant groups and each participant expected businesses, at the bare minimum, to comply with the law of the 
land. Consumers and policy makers were generally of the view that businesses did not have compulsory responsibilities or obligations beyond the requirements of the law. This is because they thought that it was the role of government to establish the minimum requirements and, accordingly, the obligations of a business. This was seen as a suitable arrangement because the participants thought that businesses would not accept any social responsibilities that are not also obligations.

In my experience, the only responsibilities they are prepared to accept are responsibilities that are hoisted on them, like tax or pollution. Businesses are happy to freeload and are very unhappy to account for their actions (Consumer Two)

However, some consumers and policy makers thought it was in the best interest of the business to act beyond their immediate obligations as this would not only avoid harmful regulation, but would also attract consumers.

Although all business participants thought that businesses had to obey the law, they thought there was more to meeting a minimal standard of operating than just legal compliance. Compared to the other participants groups they placed a higher standard of responsibility on themselves. This was unexpected. The individual responses of some of the business participants help to explain this outcome. One business participant noted that because businesses are part of society they have an obligation to be a good member of that society. Another noted that "one of the problems of just complying with the law would be that all social expectations that are not legislated would be ignored" (Business Three). This is an important point because the business environment and social expectations move at a far greater pace than parliament. These results suggest that business participants thought businesses had obligations beyond the law.

Participants also expected businesses to be fair or ethical in their dealings with their customers (as a minimum). This expectation was clear from consumer and policy participants. However, the meaning of fair and ethical is ambiguous. Consumers saw fair and ethical as meaning fair treatment or being treated as an individual, not being racially profiled or even something as simple as good after sales service. Policy makers saw fairness or ethics in a purely legal sense. One policy participant stated that "the law reflects society and the values we have and how we want businesses to behave" (Policy one). In other words, businesses will be acting fairly and ethically if they act according to the standard set by the law. The policy participant's statement was qualified with reference to the spirit of the law; the participant thought that the purpose with which the law was made should also provide guidelines for the way in which businesses should 
behave. A couple of policy participants also thought that businesses had to be good corporate citizens.

Fairness and ethics were also a common theme among business participants. However, the much stronger theme among business participants was that businesses have a responsibility toward stakeholders or should 'have a balanced stakeholder approach' (Business three, four and five). A balanced stakeholder approach is where an organisation does not favour shareholders at the expense of others stakeholders such as employees and customers (for example, by issuing generous dividends after making staff redundant or lowering the quality of products). Another participant observed that businesses are artificial constructs composed of and made up by people (Business six). This means that businesses are composed of elements of society and only exist in a legal form that we allow it to. This makes legal compliance and ethical practice an important part of a business' operations. Although all business participants thought that businesses have responsibilities beyond the law they also thought that these responsibilities were separate to the core function of a business. The core function of business, according to these participants was the activities which resulted in profit.

\section{Satisfaction of Customer Needs}

Most participants expected businesses to have responsibilities beyond legal requirements. Many participants expected businesses to satisfy consumer demand, while all participant groups thought that a business which satisfies market expectations (social and economic) would be more viable. In fact the prevalent view among consumer and government participants was that satisfying legal minimums as well as meeting market expectations (seen as a responsibility by some participants) was the extent of the responsibility of business. This result almost certainly reflects the respective positions of each participant's role in society (consumers set market expectation and the government sets minimum standards). However, consumers did not have a general expectation of how all businesses were to behave toward them. What was important to consumers was that they expected to have their individual needs satisfied and indicated that they would be more likely to buy from businesses that could do this. Some consumers had an even stronger view, stating that the responsibility of business was to satisfy their needs. These could range from pure economic needs to needs relating to environmentalism, nationalism and protectionism. Such a result makes it difficult to define market expectation and social responsibility. One consumer observed that satisfying consumer demand or expectation is the principal measure of a responsible business. This was also reinforced by government participants and the expression that businesses are there to "make profit and respond to market signals" (Policy six). A business participant stated that businesses need to deliver on their value 
proposition (how they deliver value to their customers). Their value proposition should guide the way in which the business meets the market's expectations. Most business and some government participants also indicated that businesses must adapt to market expectations as well as issues in the macroeconomic environment. This means that meeting legal requirements is not enough for a business to be responsible. However, whether or not a business intends to be responsible, business strategy would seldom be made in isolation of the wider strategic environment.

The results so far have shown that the participants thought the responsibilities of business include compliance with the law and satisfaction of customer demand. The next section explores how businesses are responsible for acting in a manner that will ensure their own future profitability and survival.

\section{Strategic Self Interest}

The majority of participants (mostly consumers and policy makers) did not believe that a business had any mandatory responsibilities beyond obeying the law, acting in a fair and ethical manner and satisfying market expectations (although the latter is more an expectation of business than a rule). However, these participants thought that any voluntary acts that went beyond this could be beneficial to the business. Pure altruism was seldom raised as an example of actions beyond the law and societal expectations. Examples related to the end goals of a business or the way in which a voluntary act can cause social benefit and improve reputation and revenue collection.

They [Businesses] have responsibilities, legally, with anything else they do not have a responsibility to do it, but it can be good for them, it can be a way to sell their product (Consumer one).

Businesses saw these social responsibilities as more of an obligation than consumers and government officials. Returning to the idea of a balanced stakeholder approach, many participants (particularly business managers) thought this was an ideal way to ensure the long term interests of the business are observed (Business three, four, five)". Participants also commented on the concerns of shareholders, employees and customers as important stakeholders; this was referred to as a triangle of primary stakeholders. Consumer and government participants did not see stakeholder management as a function of a responsible business, but this may be because these participants thought it was a typical business activity. 
A common theme that emerged, and one that ties into the strategic environment, was that businesses should exceed minimal standards of responsibility because it is in their interest to do so (although this was not an expressed as a mandatory responsibility of business, it was perceived as something participants expect from a sensible business). In other words, a business can benefit from exceeding its immediate obligations. This was referred to as self interest or "enlightened self interest" (Policy seven). Enlightened self interest is the realisation that doing well can either directly or indirectly bring back good to the organisation or at least mitigate some harm or protect a business' brand. A government participant used an example of enlightened self interest by referring to organisations which are able to keep their best staff by maintaining high labour standards. Social responsibilities like these were considered by participants to be investments instead of liabilities. This result suggests that the participants expect businesses to behave in a selfish way, but that the community should not be adversely impacted by the business' behaviour. Another business participant stated that 'businesses have a vested interest in the best functioning of society (Business six)". This means that businesses can do well by acting selfishly and being good (incidentally or not). In addition, it also allows businesses an opportunity to be perceived as good and to market itself accordingly.

A business which exists to make money, complies with the law, meets markets expectations and acts in strategic self interest, can be called 'the responsible business'. This definition of responsible business has been defined to include social responsibilities that would directly impact or benefit the business. However, there is one more element to this, this is where the business, either accidentally or deliberately causes harm.

\section{Mitigate Harm}

One of the most interesting themes from the results concerned the concept of harm. The majority of participants believed that businesses should conduct their business in a way that does not cause harm to others. While there was little disagreement on the opinion that businesses should be held accountable or responsible for their actions, especially where harm is caused to others, participants differed in the definition of harm. Some saw harm as a direct consequence of an organisation's actions or negligence, such as BP's oil rig disaster in the Gulf of Mexico, while other participants saw harm as the indirect consequence of a business' presence or actions, such as when two firms enter into intense competition, one loses and the employees of that firm are made redundant. The competitive practice indirectly makes the employees of the other firm redundant. The difference in meaning carries a significant difference in responsibility: the former keeps responsibility tightly defined, while the latter is potentially infinite and would be difficult to track, manage and be held accountable for. 
There was significant disagreement over whether businesses should be responsible for indirect harm or social ills. Most participants did not think that businesses were responsible or accountable for social ills (social ills such as crime, lack of education and unemployment were seen as social problems to be handled by the government). Most participants did not think that businesses were responsible for any social harms or ills that were not statutorily defined. This means that it is difficult for businesses to commit social harms without also breaking the law. One business participant thought that businesses were responsible only for causing direct economic harm, while other business participants referred to the concept of 'doing no harm' as 'minimising externalities' (Business Two, Three). By avoiding externalities, these participants meant that businesses should actively avoid causing harm to persons or property outside of the business. This will avoid the possibility of the externality having, in turn, an adverse impact on the business. The process of minimising or managing externalities is a self-interested action. Policy participants had a similar view: "I am very attracted by the notion that people who impact on the lives of others have a responsibility not to do others harm" (Policy seven). The same policy participant stated that businesses have a social contract with society, which sets "societal levels of decency, that dictate how people should interact with each other (Policy seven)". This participant thought the social contract was something above the legal minimum, something that we expect from business. However, this may be nothing more than merely matching the cultural standards of the community you are in, understanding the impact of local events (such as expectations of leniency and generosity (in situations such as the recent Canterbury Earthquake) or satisfying individual customer needs.

A couple of business participants thought that businesses had an obligation to repay (through charitable activities or general CSR) any economic cost that is either a direct or indirect result of the businesses presence of activities.

In a way businesses are taking profits away from the community. I think businesses have some level of responsibility to support the economy that they operate in, because without that economy their business does not exist (Business two, four)

In addition, a couple of consumers and a solitary policy participant claimed that businesses were "taking money out of the community" (Policy four, Consumers four, seven). These participants thought that these businesses were foreign owned and therefore gave nothing back to the community. One consumer stated: "Businesses have a responsibility not to rape society's resources, you know, not to have slave labour overseas" (Consumer four). In addition, a couple of business participants thought that businesses should pay back society for use of its resources. No mention was made of businesses' contribution to the community though employment, use of local suppliers, investment and provision of goods or services. The word 
rape also suggests that some participants think that businesses are there to exploit or illegally use resources in the community. These responses create the impression of business as a cost or as a burden on society, with little or no mutual benefit to society. These responses relate to earlier views from a couple of consumers, who considered that businesses would get away with what they can. However, the views of the business participants, who thought that businesses were taking money out of the community, are remarkable in the sense that business participants said this. This suggests that some businesses believe they are harming the community (by being profitable) and therefore they feel they have to engage in social responsibility to make things right. It seems strange that business managers should feel guilty about earning profit. Indeed, why should business managers think that they have a responsibility to the community?

One of the reasons behind why a business would feel responsible for harm caused becomes clear through some of the participant responses. One business participant noted, and this was reflected in the comments of several others that "I think you get what is coming to you, people find out about what you do. I think you have an obligation to understand the impact you are having (Business three)". The motivation for doing well in this context comes from a belief that irresponsible actions will bring harm back to the organisation. This is very much the moral law of causation (Karma). Avoiding harm or being responsible for harm caused is a way of avoiding future harmful actions (or doing good deeds is a way of avoiding bad reprisals). Although it is highly unlikely and impractical for businesses try to cross out one bad deed with another unrelated good deed, the concept explains the motivation for businesses to avoid doing bad actions and focus on taking good actions. But perhaps the motivation is misguided: It is interesting that some business participants felt an incentive to avoid either deliberate or accidental harm because of the possibility that some power in the universe would cause reciprocal harm.

This theme of avoiding harm is similar to enlightened self interest, but suggests that if it was not for the fear of retribution for harmful actions business participants would not be as concerned about committing an irresponsible action. However, some businesses seem genuinely concerned with doing good, not out of sense of avoiding harm, but to make "the world a better place" (Business 4).

\section{Making the World a Better Place: The Extreme Interpretations of Responsibility}

The idea that businesses should make the world a better place extends the role of business beyond obeying the law, meeting market expectations, acting in strategic manner and avoiding harm. In the literature review, it was argued that businesses make the world a better place 
merely by existing (and even by merely making money). However, some business participants claimed that businesses are not only responsible for non-corporate social change, such as righting social issues, fighting poverty and improving the environment, but that they should also be leading this change. This is usually the domain of NGOs and charities, whereas businesses are usually concerned with improving our lives through product development and delivery of goods and services that satisfy our needs and wants (or create them!). Businesses which wish to make the world a better place can be defined for the purposes of this research as a social business. In these businesses profit making may be on par with creating social good. Social good would be a mandatory part of business. The difficulty in this approach would be defining social good, deciding on which social good should be promoted and to ensure that the business is responsible for a tightly defined social good (the risk for the business is that the responsibility for social good extends to cover all manner of social good which has no relevance or interest to the business).

In contrast, policy makers stated that it was their role and the role of government, and not the role of business, to be the agent of social change. Policy makers considered it their duty to determine social good and to regulate in accordance with social norms and social good. However, policy makers thought that businesses should strive to set best practice and create benchmarks to improve their offering and conditions of employment. One policy participant detailed a business owner who insisted on making his products environmentally sustainable despite no legislative requirement, demand or additional cost. The rationale for acting in this way was to do something that aligned with the client's values and beliefs. The policy participant stressed that this was not expected of businesses, but that businesses are free to conduct themselves in this way.

There seems to be a conflict in how businesses engage in social issues (or whether businesses should at all). There is also a significant difference between a business which acts in strategic self interest and avoids harms to others 'the responsible business' and a social business. The responsible businesses would be involved in social issues which are directly relevant to the organisation, such as a manufacturing business addressing a skilled-staff shortage by offering to train staff in communities with high unemployment.. This would be where the organisation can cause and receive benefit from the community or where it is actively trying to mitigate or eliminate any harm that it is causing. However, such actions would always be voluntary. For the responsible businesses, the social issues are part of the operational environment. In contrast, the concept of the social businesses suggests that making society a better place should be a core part of business. While the social business may exist in theory, in practice it would have a confused purpose. 


\section{The Role and Responsibilities of Business}

This chapter has addressed the first and second research questions. The first research question aimed to understand more about the purpose and role of business and the second aimed to understand what businesses were responsible for. The results in this chapter showed that while participants thought that the purpose of going into business, and indeed operating a business, was to make money, that businesses were responsible, to society, for things beyond this. These responsibilities included compliance with the minimum standards of the law, meeting community and market expectations and avoiding harm. Most participants did not expect businesses to engage in voluntary activities that did not result in benefit to the business nor did they expect business to lead the field in fixing societal problems. It was only a minority of participants, and these were business participants, who thought that businesses were required to promote and enact social good beyond their operations or presence. However, most participants thought that if a business could act in a way that could benefit both their business and society then they should.

A number of models for business responsibility have emerged from these results (see diagram below). The first is the temporary business, where focus is only on legal compliance and where customer satisfaction is not satisfied, meaning that the business is likely to have a short life span. The second is the average business which meets market demand and complies with the law but fails to engage in acts which ensure its long term survival. These could be anti competitive acts or disastrous public relations management. The responsible business, in contrast, complies with the law, meets market demand, acts in a way to ensure its long term survival and, tied to this, negates any harm it causes. The social business goes one step further by incorporating the welfare of society into its business functions. But it is debatable whether this type of business acts in strategic self-interest since many social problems will have little connection with the business' operations.

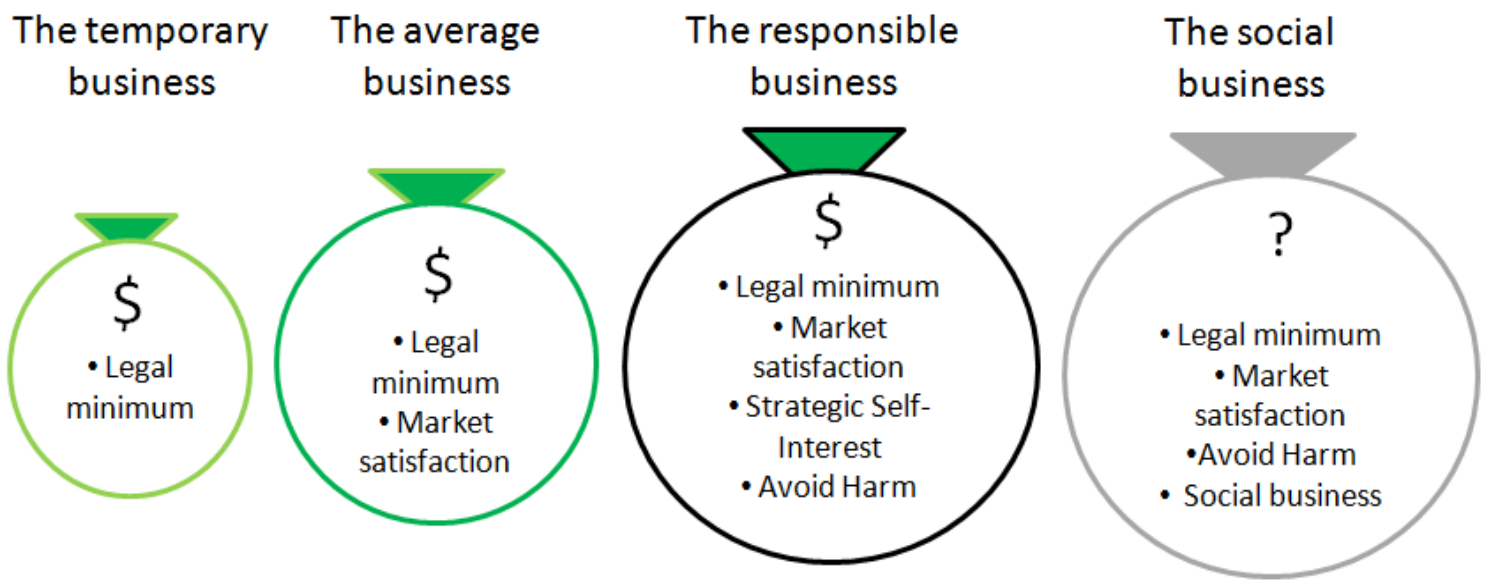

Figure 1: Money bags and a mystery bag: the various models of responsibility. Note that these models also summarise the findings of this chapter 
The results and general view of the participants were used to create the responsible business model. Only a small minority of participants thought businesses were responsible for making society a better place. The responsible business would also make the best transition from theory to practice because the social activities the business engages in would be directly relevant to the long term interest of the business and will not divert the business' attention from its core activities. This means that any voluntary CSR should make an overall positive contribution to the business' profitability. In contrast, the social business risks losing the benefits of a strategic CSR program and being distracted from its purpose.

One of the other issues in these results is the difference between mandatory, strategic and voluntary (or additional) responsibilities. Many participants stated that businesses are responsible for complying with the law while others stated that businesses are responsible for making the world a better place. Indeed some participants would like to see this as a mandatory obligation of business. What needs to be stressed is that the stronger themes in this research argue that all non-legal social interactions and responsibilities should be voluntary and undertaken where there is a strategic and social need. This is where, for example, a business which voluntarily engages in social interaction that is tied to its operational strategy is likely to profit from it and a business which is self interested will do this. This is in contrast to a business which will engage in a wider and less relevant array of social activities that are unrelated to its operations. In some cases this is justified, particularly where there is a business owner-operator who feels connected to a social cause and dedicates resources to it. What is important is that these activities are not treated as obligations.

The results in this section as well as the responsible business model align closely with much of the literature concerning stakeholder and CSR theory. The following section will elaborate on how these results relate to the literature on business and society.

\section{Discussion}

The results and themes in this research have indicated that the participants believed that businesses are responsible for legal compliance and satisfying customers. Along with this businesses should act in a self interested manner and avoid harm to others. This is a definition of a responsible business and a response to the debate in literature on the social responsibility of business.

The business and society literature, in the literature review, focused on competing views on the role of business in society (the argument about whether the pursuit of profit is enough). The 
majority of participants in this research had views that supported the view that role of business is to make money (Friedman, 1970; Gamble \& Kelly, 2001; Vogel, 1991; Kerr R. , 1998; Barry N. , 1999; Goodpaster, 1991). No participant thought that the purpose of business was to fix social problems or to make society a better place (although some participants thought that businesses had a responsibility to do this). However the results showed that all participants thought that businesses should comply with the law and meet customer expectations. However, there was some significant divergence between (and among) participant groups in other themes.

In general, consumer participants valued, above all else, businesses that satisfy legal minimums and offer something that will satisfy their needs, wants and expectations. This supports previous research which argues that consumers support satisfaction of minimal requirements and do not expect more (Bird, Hall, Momente, \& Reggiani, 2007; Davis I. , 2005). Policy participants expected businesses to meet their legal obligations and expected businesses to act in a self interested manner, while business participants thought it was their role to satisfy consumer demand, make a positive contribution to society (or cause a net benefit) and make money along the way. Although all but one business participant thought that businesses existed to make money, many of these participants thought that businesses had responsibilities that were unrelated to making money. These responsibilities ranged from not doing harm to being a good employer to making the world a better place. In fact some business participants supported the position that businesses had a responsibility to further social good (e.g. (Barnett, 2007; Montiel, 2008; Davis K. , 1973; Hubbard, 1999), while the views of policy makers and most customers thought that businesses had to only satisfy legal and market expectations (Barry N. , 1999; Kerr R. , Business as a Vocation, 1998; Goodpaster, 1991; Friedman, 1970).

However, there is a conflict between what consumers and policy makers think the responsibility of businesses is, and what businesses consider their responsibility to be. The role of these participants is for consumers to buy the goods that businesses supply and for businesses to provide and sell these goods according to the boundaries the government decides best meets the interests all groups. The responses of consumers and policy makers tied with their respective roles, while the general response of businesses was to extend their responsibilities beyond legal and market minimums. This is peculiar, especially since the literature which supports narrower views on the roles and responsibilities of business is supported by business lobby groups and argues that businesses are responsible for making profit and little else (Kerr R. , 1998; Barry N. , 1999). I expected business participants to distance themselves from any expectation of non-profit related activities. There are a few reasons which could explain how this result emerged. One is that businesses are both the participant and subject of the interview and may feel compelled to answer in such a way that makes the speaker come across 
positively. If the subject of the thesis was about the role of government in the private sector, policy makers and business managers may have answered in completely different manners. The policy participants may have felt defensive while the business participants may have felt more assertive. Another possible reason is that businesses believe strong social responsibility rhetoric will act as a safeguard against regulation or, alternatively, that a good deed should be done to cross out every bad one. Another reason, as addressed in the results section, is the idea of harm or karma (which will be discussed in the next paragraph). The final reason is that many of the business participants genuinely believe that it is within the scope of business responsibility to do well and make the world a better place.

The theme of doing social good, or the way the business participants conveyed it, seems to be related to the theme of avoiding harm (or trying to make up for harm done). The idea of harm was also a key point of divergence for participants. Some business participants (as well as some consumers and policy participants) thought that businesses were doing harm ('taking money out of the community') to society through their mere existence.

...[l]f you are destroying or utilising a town's natural resources you should have a requirement to put back to those people, you should have a commitment which goes above and beyond the norm (Business two)

I think businesses have a responsibility to the community they are trading in. I believe they are taking money out of the community and that they have a certain obligation to be involved in the community in a positive manner (Policy four).

Although this theme and the above quotes were present across all participant groups, they were a minority view. Righting historic wrongs or crusading to make society a better place are noble causes, and businesses that voluntarily engage in these activities should be praised for it.

However, most of these activities will distract businesses from their purpose. The results suggest that participants do not expect businesses to be righting social ills. In fact, participants generally thought that businesses made a positive contribution to society. Most participants viewed harm as something businesses should avoid doing while taking responsibility for any harm they cause to others. This reinforces the literature on stakeholder theory and the argument that people should be responsible for their actions and that businesses need to understand the impact of their actions on others (Freeman \& Phillips, 2002). The difference is that these 'responsibilities' are a direct part of business and not a distraction to it. The idea of responsibility for harm caused to others is well entrenched in western legal systems. In New Zealand, our Tort/Civil law system is based on correcting non-criminal harm done by people to each other 
(Aitkin, McLay, \& Hodge, 2006). This literature on harm and the findings of this study state that businesses are responsible for providing a duty of care to those who are affected negatively by the actions of business.

The finding that most participants thought businesses should be accountable for direct harm but not responsible for righting unrelated or indirect social ills (or indirect social ills) suggests that profit made without harming others is both morally permissible and expected. The idea of direct harm suggests that an organisation is responsible for harm dependent on how proximate the business' activities are to the affected party. This would include damage to the environment, an unsafe environment, racism, causing injury or poor health to the community or any breach of the law. Businesses have a great power to do poorly to a large number of people. This relates directly to the stakeholder literature debate. The stakeholder literature has various interpretations and views on what a stakeholder is. In this case, the ability of an organisation to cause harm (or good) directly to someone determines whether an organisation has a responsibility to that person and whether any reparative actions should be taken. The power to cause harm to others means that a business has a duty of care. This relates closely to what Ihlen (2008) calls the 'normative stakeholder', a stakeholder whom the business has a moral responsibility to. It also reinforces the conservative view of social responsibility as minimising harm and taking accountability for any harm caused (Campbell, 2007; Mohr, Webb, \& Harris, 2001). This means that the relevant stakeholders to an organisation, in the sense of business responsibilities, are the ones an organisation can do direct harm or good to. It also ties into the second half of Milton Friedman's definition of stakeholder: "any group or individual who can affect or is affected by the achievement of the organisation's objectives" (Friedman, 1970, p. 46). The first part of Friedman's view can also be applied here; the management of harm focuses on stakeholders impacted by the organisation's activities but also acts to avoid harm returning to the business. In my view, managing harm should be strategically managed by an organisation. It is in an organisation's best interest to take responsibility for direct harm. Being responsible, in this sense, not only satisfies the views of most participants in this research, but it is also a better way of understanding how organisations should act in strategic self interest.

The concepts of responsible businesses and social businesses emerged from the results. The responsible business was one which, in carrying out its business activities, managed externalities and operated in long term self interest while choosing whether or not to participate in CSR which was directly relevant to its operations. In contrast, the social business made social good a core part of business. These new concepts tie closely into the debate in literature on CSR. The 'responsible business' is strongly connected to ideas on strategic CSR. Strategic CSR argues that any CSR should be related to the business' value chain (Porter \& Kramer, 
2006). The concept also supports the idea of strategic self interest and avoidance of harm referred to in the above paragraph (Mohr, Webb, \& Harris, 2001). In contrast, the social business supports CSR in a more generic social context. It ties closer to corporate philanthropy and to the idea that business should do more than just make money (Hubbard, 1999; Smith \& Ward, 2007). The prevalent themes in this research support the concept of the responsible business over the social business. What does this mean in terms of impact on the literature on CSR and business and society? It means that the findings support the more conservative or 'strategic' literature on CSR referred to above. This literature argues that CSR is not a core part of business, but that it can be an important voluntary element that should be engaged in when there is a clear connection between the operations of a business and a social need. It also argues that CSR should be viewed and managed from a self interested, utilitarian perspective.

The analysis and subsequent discussions have focused on the main themes and the similarities and divergences between and within participant groups. The analysis and discussion have allowed the following construction of a responsible business: compliance with legal minimums, satisfaction of market expectations, strategic self interest and avoidance and/or accountability for direct harm. This concept of a responsible business is strongly supported by most participants but the wider concept of harm causes disagreement. The majority of participants support the idea that business is responsible for direct harm while the minority thought that it is within the scope of business responsibility to fix indirect harm, social ills as well as make society a better place. The findings in this chapter also tied closely and made contributions to the literature and debate on stakeholder management and CSR by creating the concept of a responsible business. The following chapter provides context for these findings by exploring what impact economic context has on the role and responsibilities of business. 


\section{Data Analysis (2): The Influence of the Economic Context on the role and responsibilities of Business}

[The responsibilities of business] are the same as it any other time. The purpose of business is to make money. In a recession the market signals will be different, segments of the market will be declining as a result of changes in preference and demand so businesses will be responding in order to maximise their profit (Policy five)

\section{Chapter Overview}

The previous chapter addressed the first and second research questions. The questions were answered by exploring the purpose of business as well as business responsibilities. It did not address any sort of context, economic or otherwise. The purpose of this chapter is to introduce economic context and the concept of profit to see how these factors influence what participants think the role and responsibilities of business are. This chapter seeks to answer the third research question and by doing so, provide additional insight on the first two research questions. The third research question is: does economic context influence the role or responsibilities of business?

This chapter follows the structure of the previous chapter. It also makes a contribution to the literature on business and society by addressing the lack of research into the relationship between economic context, profit and business responsibilities. The chapter starts by reexamining what the purpose of business is in a recession and then goes onto explore the responsibilities of business (in a recession) and draws out a set of core and peripheral responsibilities. A number of models are presented to summarise this and to show how the findings from this study are relevant. This is followed by an exploration on whether profit has any relationship with responsibility and the 'virtue' of profit. These themes are then drawn together in a discussion of the data. Finally, a further discussion section looks at the similarities and differences between the results of the two chapters and attempts to draw a greater understanding about the role of business in society and the influence of economic context on the role of business.

\section{Businesses Still Exist to Make Money}

A large majority of participants thought that the purpose of a business in a recession either did not change (i.e. purpose was to make money) or was to survive. This was a consistent theme across all participants groups. 
The purpose [of business] doesn't change at all, I don't think the recession alters it one iota. It may impact on what it can do or is able to do, but I don't think it changes the objectives or the purpose of the business (Business three).

They are supposed to look out for themselves and they've got do what is necessary to survive. They've got to do what is best for the business. If that means laying off employees or cutting their wages, then they've got to do that to survive (Consumer four)

One business participant stated that making money and surviving were the same thing.

It [the role of business] does not change; the issue is that it is harder to survive. All economic activity takes place in an environment of uncertainty and what happens is, in good times, in which we have just had a very long period, you can be lulled into believing that the times are always going to be good. (Business six)

Essentially, survival and making money drive at the same points. One maintains that the purpose of business is to make money regardless of economic context, while the other suggests that businesses need to survive by making the money it needs by improving its performance or cutting down its costs. Where the two differ is in the way the purpose is achieved; making money should result in increased profitability, while survival may include the sale of assets or staff cuts. However, cash flow is still necessary for the business to continue operating. There were also some consistent minority views, with a few participants stating that the purpose of business in a recession was to provide and maintain employment and to protect national interest (protect New Zealand jobs by buying New Zealand products from New Zealand organisations and boycotting anything not made in New Zealand). These views were reflective of a small number of participants. However, the prevalent theme for the role of business in a recession is that the purpose of business (profit) does not change.

\section{Businesses Still Have Responsibilities}

Before addressing whether the participants thought that the recession had any influence on a business' responsibilities, it is useful to briefly explore the manner in which participants expected businesses to behave. This sets this scene for a further exploration into the relationship between economic context and responsibility. Participants generally did not expect anything less or more from business. Consumers expected businesses to satisfy their wants and needs, regardless of economic context. "I expect businesses to produce products of the same quality and the same service and to have the same respect for customers" (Consumer four). Policy participants 
stressed that businesses must comply with the law although these participants also stressed that a business' ability to comply with the law would be tested because of the harsh economic circumstances. Business participants did not think that anyone should expect anything more or less from businesses, that economic hardship does not influence or change a business' responsibilities. The result was unanimous. However, the view of participants on the responsibility of business in a recession is far less unanimous.

In the previous chapter, the results suggested that the purpose of business was to make money and that businesses are responsible for operating within the boundaries of the law, satisfying market demands and taking responsibility for any harm caused. However, these results did not take account of the recession and whether the recession has any impact on the responsibilities of business. This shall now be addressed. A large majority of participants across all groups said that the recession has no impact on the responsibility of business. In fact, the general view was that economic context, whether favourable or not, does not increase or decrease responsibilities.

l'd say they [responsibilities] are the same as before ... In terms of the way people behave and their behaviour as a good corporate citizen and member of society - it shouldn't change (Business three).

In terms of economic context, most participants thought that a business' responsibilities were static. Government participants, who were focused on legal compliance, stated that the economic context on its own does not change the law even if it creates more pressure to be compliant. But the recession is no excuse for non-compliance.

I can't see why it would change. In a recession, a lot more firms will be shutting down, so you want to make sure that they facilitate the shedding of labour in a way that is consistent with society's values. There is regulation that defines certain standards of behaviour, and I'm not sure if we want to go beyond that (Policy five).

Consumers thought that businesses needed to satisfy consumer needs whether the economy is growing or shrinking while most business participants thought that there was no change in responsibility.

I don't think their responsibilities change when they are in an environment of growth or recession. They just do what they have to do to survive. Ideally, people wouldn't lose their jobs, but if layoffs need to take place for the business to survive, then that is understandable (Consumer five). 
Business participants generally thought there was no change in responsibility. "I don't think the recession changes the responsibilities a business may have" (Business three). The responsibility of business in a recession is the same as at any other time and economic context does not matter.

Instead of focusing on additional responsibilities, business participants thought that businesses should be focusing on the opportunities presented by the recession. This might involve businesses seeking new business opportunities, orientating toward consumer fear and interest or an opportunity to make the business leaner. Many participants stressed flexibility and adaptation. Most participants stated that a business's response to a recession is not about a change in responsibilities or lowering legal thresholds to make the weaker businesses survive; it is about adaption to the challenges in the new environment. Invariably, some businesses will fail, others will struggle, while others will profit out of the recession. Also, a recession is not the only time that businesses fail. They can fail at any stage. One business participant, citing the continual state of success and failure of business also stated that "businesses that are succeeding will take up resources that have been freed up, this is what makes capitalism work and it moves resources from the least efficient to the most efficient" (Business 6). Policy participants thought that businesses should be doing what they usually do: obey the law and meet (the change in) market expectations. Consumers stressed the importance of either creating or maintaining staffing levels. This was a theme consistent with business participants and to a lesser extent, policy participants. In some cases this was represented as a responsibility businesses had during a recession (this remains a minority view).

A couple of participants from each group thought that the economic context gave businesses additional responsibilities. Most participants reaffirmed the same responsibilities, such as legal compliance and minimising externalities that are mentioned above, however there were slight variations. A small number of business participants said that businesses were responsible for maintaining business confidence as this would help the economy ".. in maintaining staff and maintaining a positive outlook. If business was to act negatively at the first sign of bad news, we'd have a lot of problems in the market" (Business two). Some consumers believed that a recession makes businesses responsible for loyalty toward New Zealand (by using New Zealand suppliers and keeping New Zealanders in employment). This protectionist theme may be an outcome of media focus on struggling New Zealand retailers and suppliers, but may potentially be a result of the 'buy New Zealand made' campaign, which were funded by the New Zealand government to increase demand for locally made goods. However, most participants did not consider protectionism to be a measure of responsibility, but did raise the (perceived) responsibility for businesses to maintain employment, although this was expressed in different 
ways. Consumers referred to the need for businesses to maintain employment. A few business participants stated that they felt an expectation to keep staff employed, while other business participants said that maintaining employment was necessary for their business given that they had such a hard time finding skilled labour before the recession. Policy participants did not think that businesses had a responsibility to maintain employment. However, the general policy participant view also implied that businesses had a responsibility in the way they made layoffs (to do it in a manner that society expects). One policy participant reinforced this by saying the way that layoffs are managed should reinforce long term self-interest (Policy seven). There were also some views that were significantly more extreme. These related mostly to employment and nationalism. One consumer thought it would be a good idea to mandate that businesses employ more people, and one business participant stated that businesses should suffer for the greater good. Another thought that all foreign products and organisations should be boycotted to save New Zealand jobs.

\section{The lesser responsibilities}

The recession has made the conduct of business harder for many businesses. However, no participant thought that this meant businesses could flout the law, although a number of businesses and policy participants thought that the government could lower some compliance requirements. A number of participants also thought it would also be detrimental to ignore market demand and cause to harm to others. These are the core responsibilities of business. The peripheral responsibilities are the ones a business can make in order to survive. These would be responsibilities outside the immediate interest of business such as correcting social ills. However, the majority of participants thought it was justified to step away from voluntary activities such as charity or non profit making activities when the business is at risk of going bust.

Business should focus on core issues. Fundamentally, a business makes its major contribution to society by being a healthy business, so its number one priority has to be a successful and healthy business where you can offer people employment and do other things for society. If it fails in its prime target then it can't do anything else (Business three).

According to this view, the core driver of business, profit takes first priority. Another participant reinforced this, stating "They [businesses] have to put things into practice for their own survival. They may not be able to put as much money into sponsorship programs or whatever that they did during the good times" (Policy four). The same participant thought that survival warranted unsavoury actions, that the ultimate responsibility of business is to stay in business. If focusing on core issues means that some responsibilities can be abandoned, then these responsibilities 
cannot be very important. This result shows two things: the first is that the narrow argument against the extension of business responsibilities is reinforced by showing that business responsibilities are a set of requirements and not voluntary activities and actions like righting social ills and making voluntary contributions to the local hospital are not responsibilities. The second is related; the result undermines the argument that businesses should take on more responsibilities as it suggests that some responsibilities become voluntary when times are tough.

The findings about economic context suggest that there are different tiers of responsibility. There is a 'core' tier, which specifies the mandatory responsibilities of business and a 'periphery' or voluntary tier where businesses engage in activities that are not core or strategic to the business. An additional element can be added to the core tier, this is the strategic responsibilities which were summarised at the end of the previous chapter (market satisfaction, strategic self-interest and avoiding harm). A number of diagrams (below) explain the core and peripheral responsibility concept.

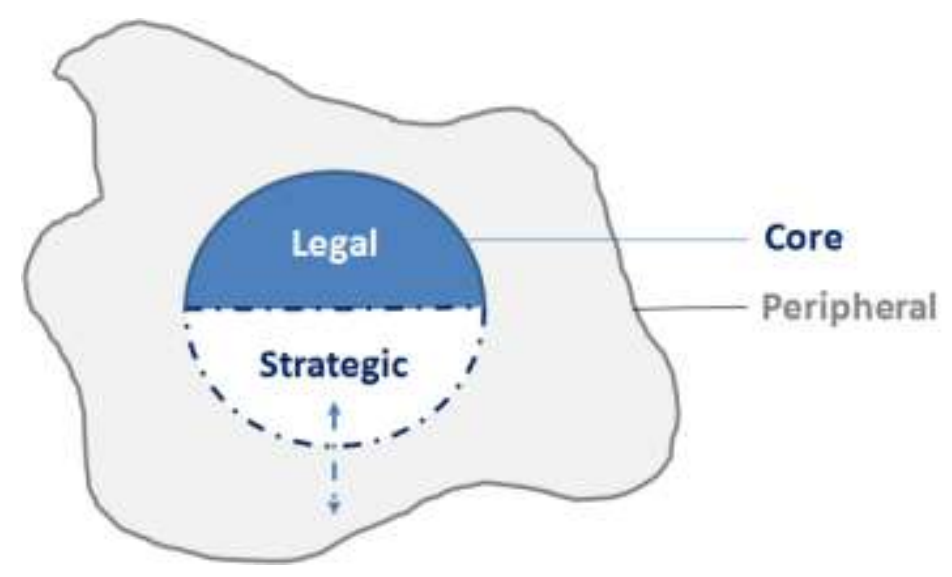

Figure 2: Summary - Core and Peripheral Responsibilities

The figure above (figure 2) demonstrates that the core responsibilities are strategic and legal responsibilities. It also shows that there is a fluid relationship between the strategic element of core responsibilities and peripheral responsibilities. This is to show that strategic responsibilities are closely related to movement in the social, economic and legal environment. The next figure, below, (figure 3 ) shows an expanded diagram which breaks the core responsibilities into legal (minimum requirements) and strategic (strategic requirements). This diagram also provides both the essential elements of responsibility (minimum requirements) and the strategic requirements. 


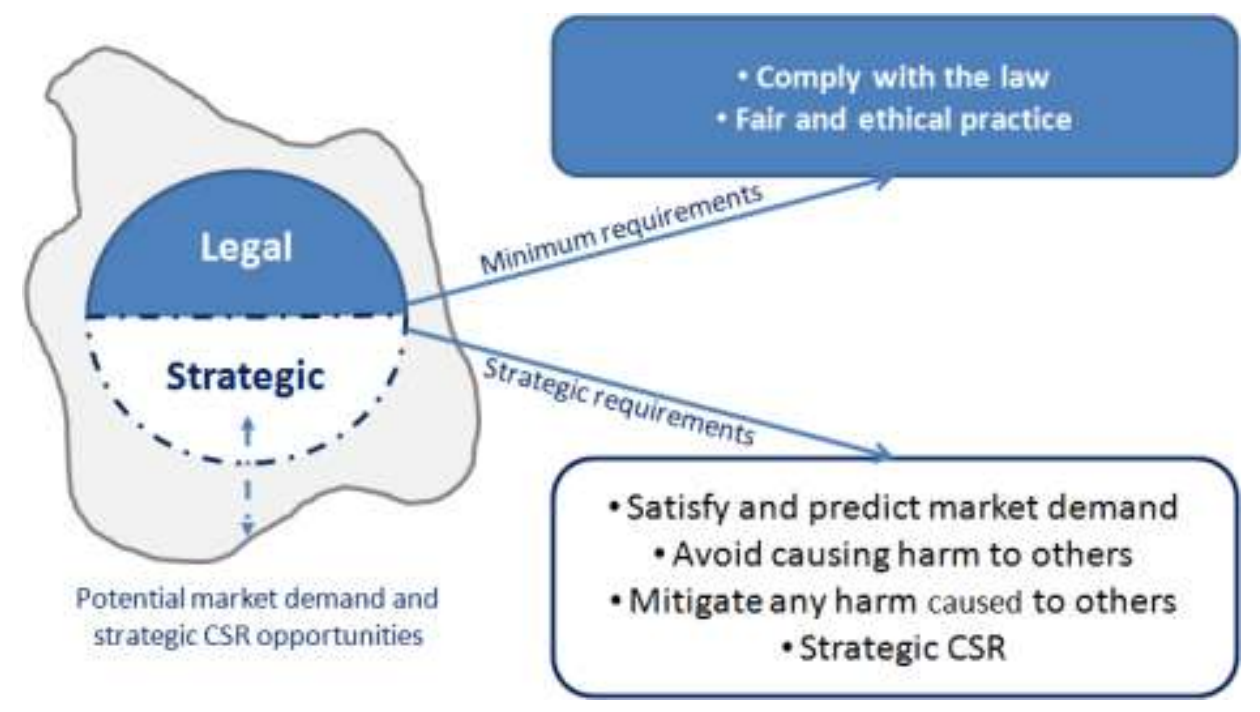

Figure 3 - Break down of Core Responsibilities

The final diagram, below, (figure 4) focuses on the peripheral responsibilities and includes examples of what these could be.

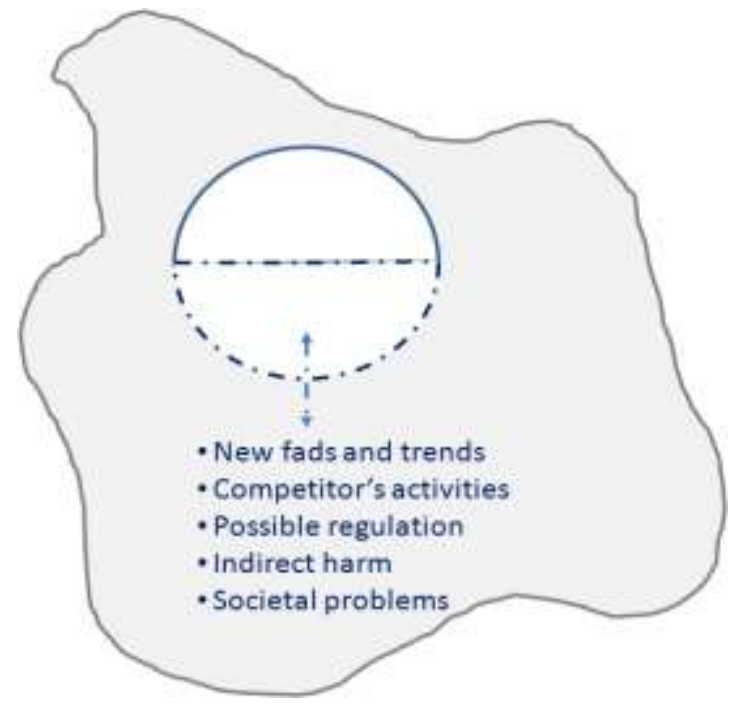

Figure 4 - Break down of Peripheral Responsibilities

The concept of core and peripheral responsibilities has emerged through exploring how economic factors can influence business responsibilities. While the general theme from the participants is that the recession has no impact on business responsibilities, an exploration into the participants' responses (and the rationale behind these responses) has allowed a greater understanding of business responsibilities. 


\section{My obligations are the same as yours}

In an earlier section of this chapter, it was stated that most participants did not think there was a relationship between economic context and a business' responsibility. However, the participants were also asked whether a business' level of profitability would influence its responsibilities (in the context of a recession). Most participants did not think that the level of profit a business has determines its responsibility. "Businesses are in a constant state of success and failure; responsibilities are independent of economic context" (Business six). In addition, the participants did not think that profit earned in any economic context had any impact on responsibility. In fact, most participants thought that unprofitable businesses were bound to the same standards as profitable businesses and that this was applied regardless of the economic context.

Businesses are lucky if they are profitable in a recession. They don't owe anyone anything and they do not have any responsibilities because of it ... again I see the point of business to make money and sell products people want to buy" (Consumer one).

Most consumers, like most policy makers, saw no relationship between profit and level of responsibility or saw the relationship in purely utilitarian terms, which could be viewed as a simple market exchange (the purchase and sale of goods) which benefits both parties. Many business participants were opposed to the idea that the level of profit they made had any impact on their responsibilities. When asked whether a profitable business, in the context of a recession, had any responsibility, one business participant stated:

No, I don't think you can make that distinction. The best way to think about this is that you've got lots of businesses in the market place that are seeking to survive, sometimes the economic tide is going in and is in favourable and other times it is not (Business six).

Another participant stated: "should the business turn around and employ more people because the unemployment rate is going up. No? It comes back to the fundamental driver - that is to be a successful business" (Policy one). Other participants across all groups had similar views, stating that a business' success is indicative of its contribution to society and that "a profitable business does not owe anything to anyone [by the mere fact that it is profitable]" (Consumer one). One business participant became animated about this issue detailing how people were jumping on his back', trying to squeeze every dollar they could from him. Another business participant suggested it was pointless being socially responsible (in the wider sense of the word) when the business is failing. "The major contribution from business to society is to be profitable, there's no point being responsible if you are making a loss" (Business three). This result suggests that CSR is subordinate to profit. 
There were a couple of consumer participants and two policy participants who saw the relationship between profit and responsibility differently from all other participants. These participants thought that profitable businesses had a greater responsibility to society because they are more capable of helping than other businesses. One policy participant explained this by saying "If you are doing well while others are not, if there are ways that you can assist the general economy, you do have a social responsibility to do so" (Policy four). However, most participants disagreed. "A business does not suddenly become the leading respondent because it is profitable, although some people may try to place that role on business" (Policy one). A profitable business is not necessarily a responsible business nor is an unprofitable business necessarily an irresponsible business.

The literature review discussed how prior to the recession there was a push for businesses to engage in environmental activities or to be more socially responsible. There was a feeling by some people that businesses (particularly oil companies) were earning excessively, while families were struggling to pay the bills. There was an expectation that businesses that profited at the expense of others should contribute more to society. Profit, when it was excessively earned, or made at the expense of others, seemed to be immoral. However, most participants in this research did not think that profit could be excessive unless there was nature of impropriety about it. Hence, the degree of profit is not the issue, but rather the manner in which it is created. "Profit is fair game if it is made within the rules" (Business six). Profit was only thought to be excessive when it was made at the expense of others or where there is abuse of market position, such as in a monopoly or, as indicated above, the oil prices prior to the financial crisis. Other participants thought the profit was excessive if all the profit was paid as a dividend to shareholders (or that demand may justify it). But the general sense was that profit was not excessive or bad unless there was some activity which was perceived to be immoral taking place. This section and the previous section have explored how factors such as economic context and profit influence business responsibilities. The findings suggest that economic context and profit do not influence responsibilities unless there is excessive profit. The next section explores the way in which profit is created influences business responsibilities.

\section{The virtue of the bottom line}

Rather than attributing the level of responsibility to the quantity of profit, some participants, particularly businesses, attributed it to way in which profit was earned: for example, if a business makes its profit in a way deemed unfair or unethical to others, like sacking domestic workers in the middle of a recession to employ cheaper overseas staff, these participants would perceive this profit to be less pure than profit made by supporting the local economy. 
It depends upon how they have made the money, are they profitable because their costs have gone down, because they have shed staff, or are they making money irrespective of their staffing levels. Or are they making money while keeping staffing levels, in which case they are being responsible (Business one)

This seems to suggest that the 'virtue' or purity of a business' profit depends on the action(s) that created the profit or the social cost of making the profit. "How much profit isn't the issue, it is the kind of profit that is made - how the profit is made" (Business four). It is worth noting that the business participants who considered businesses to have wider responsibilities were the same participants that thought that the way profit was produced influenced the responsibilities of business. Responsibilities, in this sense, seem to be determined not by what a business does with its profit, but by the actions it took to get there. "The level of responsibility a business has does not depend on economic context but on the activities that created the profit. A less ethical business therefore has a greater obligation to be responsible" (Business four). According to this logic, a profitable business which has earned profit while acting in a fair and ethical way, does not have any additional responsibilities, while a profitable business which is not ethical has responsibilities to make up for the lack of ethical behaviour. It is not entirely clear under this logic what responsibilities apply when a business causes harm and is unprofitable. However, the general principle seems to reinforce the earlier idea of harm: businesses are free to engage in profit making activities but should try to avoid doing harm to others and if they do, they are responsible for fixing things up (or 'purifying' their profit). This result was an interesting finding; however, most participants did not connect profit to a level of responsibility.

\section{The impact of economic context and profit on the responsibilities of business}

The purpose of this chapter was to understand more about the relationship between the role and responsibilities of business and whether the recession influenced them. A significant majority of participants thought that the purpose of business, in a recession, was to make money or to survive (by making money). A similar majority of participants thought that the recession had no impact on what they expected from business or what businesses were responsible for (although a number of participants stressed that businesses had to adapt to the circumstances). This supports the definition of responsibility that was drawn in the previous chapter (that businesses must comply with the law, satisfy market demand and avoid causing harm to others/enlightened self-interest).

A closer exploration into the influence of profit on business responsibility showed that most participants did not think that the level of profit a business had bore any connection to its responsibilities. The analysis of the data revealed a set or core and periphery responsibilities 
that supported the definition of a responsible business from the previous chapter. Finally, an exploration into a small theme, detailed how some participants thought that profit could be tied to responsibility by examining the way in which the business made its profit. This indicated that businesses that were unethical in their creation of profit were obliged to make up for their activities. The following section discusses the results from this chapter and its contribution to literature.

\section{Discussion}

There is very little existing literature on what relationship economic context and profit have on businesses or the responsibility of business (or anything much on the recession beyond immediate financial analysis for that matter). In fact there is a significant gap in literature about economic context, profit and the role of business. The results in this chapter make their contribution to the literature by exploring what is expected from business in a recession and by reinforcing and clarifying existing literature about the role of business. The purpose of including questions on the recession and profit into the interviews was to analyse whether participants thought the role of business had changed and whether participants thought businesses were any more or less responsible because of the economic context or the amount of profit (or loss) they had made. These questions were asked with the impression that a response on economic context and profit would inform the debate on responsibility by showing what responsibility is and what it is not.

One of the most interesting themes to emerge from the thesis was that profit can be good and bad - that profit could be virtuous. The results suggested that the virtue of a business' profit depends upon how the business earned that profit. In addition, that profit could only be excessive if the profit was not virtuous (for example where a highly profitable business deliberately sells poor or harmful products). Profit appears to be sinful when the activities that created it were unethical or resulted in harm to others. So it seems that responsibility, to these participants was a not a question of how much profit, but did you harm anyone in the process of being profitable? There are strong references to morality and religion within this theme. In the literature review, the link between morality and profit showed how religion influenced the way profit making activities where perceived by the public (Vogel, 1991; Paderon, 1991; Zimmerman, 1996). The results here show no sign of a negative view on profit making itself, although it may explain the responses of some participants who thought that businesses harmed society in their daily operations and were "taking money out of the community" (Business 1, Policy 4 and Consumer 4). The fact that most participants did not comment negatively on profit making suggests that the participants accept profit making as either a moral or an amoral pursuit. 
However, all the participants thought that the idea of responsibility included accountability of harm to others (which supports stakeholder theory).

However, the concept of virtuous profit is flawed. Although it supports the argument that harm should not be caused to others, it detracts from the same idea by including profit as part of the assessment of whether an organisation is ethical or responsible. Most participants thought that both economic context and profit were not relevant to responsibility - that profit should not be considered a factor in responsibility, but the actions of the business should. The theme of virtuous profit still has some moral and strategic relevance: businesses should engage in positive activities or activities that do not cause harm to others. If bad actions are committed then the business must use any gains to make up for any harm. The theme of 'doing good' or 'being virtuous' is a common theme throughout the results of this chapter and the one before it. However, the focus here is on money and how some participants have tied it into morality.

One of the key findings of this chapter is that the recession does not change the role of business. This is a clear indication that the purpose of business is to make money. This supports a significant amount of literature which argues exactly this (Friedman, 1970; Gamble \& Kelly, 2001; Vogel, 1991; Kerr R. , 1998; Barry N. , 1999; Goodpaster, 1991; Freeman \& Phillips, 2002). The finding also makes a contribution to literature by suggesting that the purpose of business is to make profit and this purpose is without prejudice to economic context. However, the most significant finding of this chapter, and one of the greatest contributions of this research to literature, is that the economic context (i.e. the recession) and level of profit do not change or influence what the responsibility of business is. The recession, according to most participants, changes nothing about the responsibilities of business. This shows that profit and loss, recession and growth are irrelevant to responsibility. It also shows that the responsibilities of business are mostly static. Within these responsibilities, there is of course flexibility. For example, most participants stressed that it was the business' obligation to operate within the boundaries of the law and socially expected standards/social norms and to respond to the calls of the market. However, responding to the market and to consumer trends is up to the business. The point here is that consumer demand or trends may change but the underlying responsibilities do not. A smart business will make the most out of the climate it is facing. The recession presents its own opportunities that businesses should exploit.

The results in this thesis indicated that the participants expect businesses to adapt to changes in their environment. However the recession has imposed challenging economic circumstances on businesses and has exposed some interesting participant responses relating to nationalism, protectionism and the mandating of employment (one consumer participant thought that 
businesses should be forced to employ a minimum number of staff to prevent unemployment). In this thesis these views were present amongst a minority of participants. It is important to understand that many of the participants, especially business managers and policy participants are employees (I could infer from the consumer responses that they were all employed). This makes some of the unexpected responses from business participants (businesses should try to maintain employment or that businesses should only sell New Zealand made goods) understandable, especially if their responses are motivated by fears about their own employment status. However, it was clear from the results that maintaining employment or selling locally made products was not something people expected businesses to do. These themes seemed to be expressed as individual concerns rather than something the participants expected businesses to do. Participants indicated they did not expect businesses to hold on to employees if they could not afford to, but that it would be good to if the business could. The underlying point is that the social expectations of business do not change during the recession. Although there may be things people would like business to be responsible for, the focus of business is to make profit (or in the case of a recession, to survive by making a profit). There is no expectation for businesses to engage in activities that will make them unprofitable.

The change in economic context allows businesses to adapt to the changes in the macroeconomic environment. However, the recession does not bring any reprieve of the underlying responsibilities of a business. The views of business participants regarding responsibility varied when the context of the recession and profit (or losses) were introduced. Business participants (and a few other participants) originally stated that the scope of business responsibility was wide and encompassed things like correcting social ills. However, when the context of the recession and corporate losses (meaning the opposite of profits) were introduced the same participants thought that businesses were not responsible for anything beyond the essential responsibilities. This suggests that responsibilities may depend on how much profit is made and that in some contexts responsibilities are an unaffordable luxury or even a voluntary activity. The idea that a business can abandon some responsibilities when it is unprofitable does not make sense. It undermines not only the previous responses by these participants, but also the meaning of responsibility; it suggests that there are multiple meanings of the word and, in addition, that there are mandatory responsibilities and 'opt in' or 'voluntary' responsibilities. This is where responsibility causes the greatest confusion: how exactly do you opt into a responsibility and how can a responsibility be voluntary? The definition of responsibility that emerged from the previous chapter suggested that almost all responsibilities are duties to perform a function to, for example, society, your employees, your investors or those affected by your actions. A duty is something that is essential. A business voluntarily taking responsibility for a cause, as cited in Porter and Kramer (2006), is an obligation the business has taken on its own shoulders for its 
own purposes (either altruistic or in self-interest). But the result here suggests that a business can discard wider or 'non core' responsibilities when the times are tough. However, no business has the luxury of abandoning legal compliance. It seems that responsibility has so many meanings that it begins to lose meaning.

The word responsibility has become so debased such that definitions of responsibility in literature range from eliminating harmful action to furthering social good all the while being voluntary and compulsory (Mohr, Webb, \& Harris, 2001; Barnett, 2007). Thus it is no surprise that the corruption of this word has caused all manner of confusion in the public sphere and in business CSR programs. The impact seems to be that anything called CSR seems to pass for it. The consequence of this is that some sections of society expect businesses to do more for them. Are businesses responsible for unemployment, poor education, environmental degradation or things that are not related to their activities? The view of this research is that businesses are not responsible for these things. These are not responsibilities. The results here have shown that responsibilities are duties or actions that take account of harm caused. They are not a $\$ 10,000$ grant to an orphan with cerebral palsy, these kind of activities are activities which are either unrelated or a tangent to business activities. Although, it is arguable that an improvement in the conditions of the community the business operates in may bring some benefit to the business. In fact strategic CSR argues that business should try to solve social needs that align to business strategy (Porter \& Kramer, 2006; Burke \& Logsdon, 1996). However, this 'social need' is essentially a business investment, because the purpose of investing is for future benefit (enlightened self-interest). The mistake is thinking that there is anything charitable about strategic CSR or enlightened self interest. They are just measures to expand profit. Strategic CSR is poorly named and it is certainly not an obligation or a responsibility. It is almost entirely utilitarian.

The responsibilities, or the scope of a business' responsibilities, have been a cause of much debate in the literature and the results in the previous chapter reflected this. However, the results from this chapter, and the above discussion, have argued for a narrow scope of business responsibility by showing that responsibilities can be divided into a set of core responsibilities and a set of peripheral activities. Businesses must obey the law, they should meet customer needs and should avoid causing harm to others and this should benefit the businesses in the long term. These are 'core responsibilities'. Other activities, such as making donations, are 'peripheral activities'. Economic context and business circumstances such as profit or loss do not change this core set of responsibilities. The responsibility of a business in a recession is the same as at any other time; any other activities that the business wishes to engage in are voluntary entered into at the discretion of the business, and should not be called responsibilities. 


\section{Core}

\section{Responsibilities}

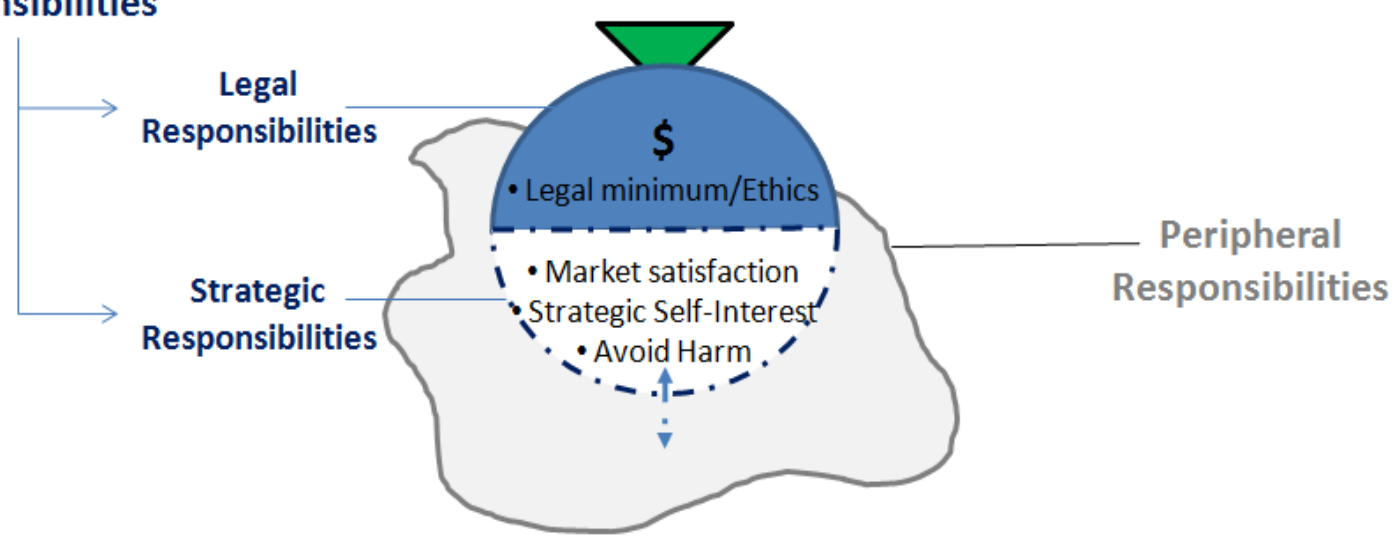

Figure 5 - Mixed models, Core and Peripheral Responsibilities applied to the Responsible Business Model

The concept of core and peripheral responsibilities relate closely to the idea of the responsible business discussed in the previous chapter. In fact, the 'money bag' representing the values of a responsible business can be superimposed on top of the core and peripheral responsibilities model (see figure 5 above). This shows that there were consistent themes between the chapters (participants stated in the first chapter what they thought the role and responsibilities of business were and these were, for the most part, restated in the second chapter). The two models (responsible business model and core and periphery responsibilities model) should provide a valuable theoretical and practical tool for understanding social responsibilities and, from a practical perspective, to exploit the opportunities for strategic self interest!

The findings of this research suggest that economic context and profit are not relevant to the purpose of a business or the responsibilities it has. The responsibility of business in a recession is no different than at any other time. The use of economic context has allowed a further understanding of CSR and has supported the underlying themes of responsibility presented in the first analysis chapter. The result of this is a better understanding of business responsibilities that businesses and academics could use in order to design and base their CSR programs on. This should not change the expectation that a business must respond to the challenges of its local environment, but it does show what activities a business must engage and in what activities it may want to engage in. The exploration into the concept of profit having a moral basis showed how morality has influenced the stakeholder principle of operating without causing harm to others. 


\section{Conclusion}

\section{Introduction}

CSR is a contentious concept and topic of research that continues to divide both the academic and business communities. The contentiousness of this topic and the political and economic debates behind it are what has made this topic so fascinating to me. The purpose for engaging in this topic and undertaking the completion of a Master's thesis was to understand more about this issue and to engage in research which could provide some insight into CSR. The financial crisis presented the perfect opportunity to do this by exploring what the public expect of and from business and whether the crisis or recession changed their expectations. Following the development of three research questions and twenty-one interviews I have been able to explore what participants thought the role and responsibilities of business were and whether the recession influenced these. This final chapter of my thesis summarises the key findings of the thesis as well as the academic literature this research contributes to. The final parts of this chapter look at the limitations of this research and the opportunities for future research that this paper presents.

\section{The Theoretical Base}

The literature review was the genesis of this research. The purpose was to explore the literature relating to social responsibility in order to find gaps in literature where contributions could be made. The literature review covered literature relating to corporate strategy, stakeholder management, corporate ethics, CSR as well as a briefly addressing the financial crisis and recession. These areas of literature are important to the thesis as they form the areas which influence the debate on CSR.

The crux of the literature review was about the role of business in society and the responsibilities of business. The debate on the role of business in society closely relates to debates on stakeholder management and the idea that a business is only responsible to shareholders and therefore only responsible for delivering profit (Barry N. , 1999; Kerr R. , 2004; Kerr W. , 2009; Friedman, 1970; Freeman \& Phillips, 2002). This is contested by CSR advocates who claim that businesses should be responsible to other stakeholders and therefore argue that a business' responsibilities extend beyond profit (Hubbard, 1999; Barnett, 2007; Davis K. , 1973). This debate is ongoing. But the argument about it has created an ambiguity about what social responsibility means and what the role of business actually is. Some researchers have responded to this ambiguity by stating that businesses should engage in 
'strategic CSR' when there is an opportunity for mutual benefit to society and the business (Porter \& Kramer, 2006; Burke \& Logsdon, 1996). In spite of this, ambiguity exists and a gap in research was identified. The final part of the literature review addressed the 2008 recession and credit crunch. At the time of research and writing this paper little substantive literature was found on whether the financial crisis changes or influences the responsibilities of business. This was also a significant gap in research as the answers from this could provide a greater understanding about the role and responsibilities of business.

\section{Revisiting the Methodology}

The objective of this research was to understand more about the role and responsibilities of business and the influence of the financial crisis on these. A methodology was designed to match both the research questions and my perspective that there was 'an answer' to the research questions.

After completing the literature review three research questions were formulated based upon both ongoing debates and gaps in literature. The research questions are as follows:

1. What is the role of business in society from the perspective of consumers, policy managers and business managers?

2. What are the responsibilities of business from the perspective of consumers, policy managers and business managers?

3. Does economic context influence the roles or responsibilities of business?

This methodology was framed within the functionalist paradigm, which means that my research not only believes there is an objective answer to the research questions, but pursues this objective answer. In order to answer these research questions a total of twenty-one interviews were completed. This qualitative data collection method was used because it supported the purpose of this study, which was to understand more about social phenomena as opposed to draw a correlation between variables. Following the data collection the data was analysed by typing the interview transcripts and coding the transcripts for themes. In the results section the major as well as the minor themes were discussed and explored.

The philosophy behind my research and the established ideas of objective and subjective, and qualitative and quantitative methodologies were something that weighed heavily in my mind. I often wondered whether I was actually engaging in functionalist research and whether it was possible to have objective results through a highly subjective qualitative data collection and data analysis method. The result is that I have a qualitative methodology and a view that there is an 
objective answer to my research questions. This pursuit of answer was softened so that the findings would contribute a 'greater understanding'. If I could retrospectively alter my methodology I would be tempted to use surveys as a data collection method and regression analysis as my data analysis. This would have the advantage of making my findings 'objective', fit within the traditional understanding of the functionalist paradigm and create a less debatable methodology; however the results may have been completely different and I do not believe that this altered methodology would have gathered the rich and detailed findings I have presented in this thesis.

\section{Key Findings and Contributions}

This research paper has successfully answered the research questions and presents important results and contributions to the literature on business and society. The key results and contributions to literature relate to how the role and responsibilities of business in society can be understood and how a factor such as economic context influences the roles and responsibilities of business.

The first key finding answers the first research question and part of the third research question. It finds that the purpose or primary role of business is to make money and that this does not change whether there is an economic crisis or a period of massive economic growth where the business is heavily profitable. This finding makes an important contribution to the debate on the role of business in society by supporting the academics and businessmen who have argued for a simple and limited purpose to the role of business (Barry N. , 1999; Kerr R. , 2004; Friedman, 1970). It also makes a contribution to literature by showing that an economic context does not change the role of business.

The second key finding answers the second research question and finds that businesses are only required to obey the law but are generally expected to do more than this. The results suggested that in addition to complying with the law 'intelligent' or 'strategic businesses' could, at their discretion, satisfy customer expectations, act in strategic self interest and avoid causing harm to others. The concept of 'the responsible business' was developed to explain these results and to show how responsibilities can be strategically managed. This finding contributes to literature by supporting the argument that a business' responsibilities are principally legal compliance (and societal norms) and anything beyond this should only be a voluntary activity (Barnett, 2007; Burke \& Logsdon, 1996; Freeman \& Phillips, 2002; Vogel, 1991). The findings also support the argument that if an organisation desires to engage in CSR it should take care to 
ensure the CSR is tied to the operation of the business and brings benefit to the business (Porter \& Kramer, 2006).

The third key finding, which supports the second, is that there are core and peripheral responsibilities. Core responsibilities are responsibilities which are compulsory and strategic to a business while peripheral responsibilities are non strategic voluntary actions or programs a business can engage in, if it wishes to. This finding contributes to literature by suggesting that there are different levels of social responsibility and that the mandatory responsibilities need to be differentiated from the strategic and voluntary responsibilities.

The fourth key finding answers the third research question. It finds that the recession does not change business responsibilities. It does not matter whether a business is profitable or not. Similarly, the profitability of a business is not a factor in its responsibilities. This finding is an important contribution to literature because the literature on economics and social responsibility is undeveloped. The introduction of economic context aimed to provide a context to understand whether expectations of business have changed. The fact that the results indicated that there were no change in responsibilities suggests that the participants in this study saw responsibilities as something static, which remained the same regardless of context. Similarly, participants did not think a business that was more profitable (or unprofitable) in a recession would have any additional responsibilities. This suggests that there are standards a business must adhere to (legal) and that economic circumstances or internal financial circumstances do not affect the social responsibilities of business.

\section{Practical Use}

The findings and contribution of this thesis are relevant to both academia and business. The findings have created a model which can be used theoretically to understand more about corporate social responsibility and also to provide some practical guidance for businesses. The practical guidance is through the creation of 'the responsible business' model and the 'core and periphery' responsibility model. These models are applicable to any for-profit business.

The 'responsible business model' shows that social responsibility programs should be closely tied into the operation of the business. It also suggests that businesses that follow this model are more likely to be successful in the long term (because they take actions which ensure their long term self interest). This is by no means guaranteed, but the model allows for guidance which is more likely to make the business successful in the long term. The second model, the 'core and peripheral' responsibility model complements the early model. It does this by showing 
what kinds of activities are compulsory, strategic and voluntary and also the dynamics between the external environment, business strategy and social responsibility.

\section{Limitations}

The findings of this study have made important contributions to literature and have provided some tools so that the findings can be practically applied. However, there are some important limitations on these findings that need to be addressed.

The first limitation is a methodological timing limitation which may have impacted the findings; the interviews were conducted during the recession. This meant that the first set of questions in the interviews, which did not include reference to the recession, may have been influenced by the climate in which the interviews were conducted. However, this limitation was unavoidable because it is difficult to separate someone from the context in which they are living. It was also unavoidable given the pressures of a limited timeframe in which a Master's thesis must be completed. The impact of this limitation on the results is unknown; however the interview questions were designed to mitigate this limitation as much as possible. Future research could cover a greater time period and explore whether there are shifts in responses or attitudes based on the context in which the research is conducted.

The second limitation is a potential limitation. In the results chapters, I discussed how some of the responses of business participants were not only unexpected but also seemed to undermine their own positions as businessmen. I speculated that this was because the business participants were the subject of the thesis and I thought that the outcome of this may have been that the business participants were not as forthright in their responses as policy participants or consumers. The impact of this on the findings does not seem to be large (admittedly, I can only speculate as to if a business participant was giving a misleading answer) because the majority of business participant responses were largely in line with the responses of other participants. Future research could take the form of an anonymous survey where the subject of the research may feel less obliged to answer in a manner which ensures that the subject is portrayed favourably.

The third limitation is also a potential limitation, but needs to be addressed. The sample size for this research (a total of twenty-one interviews separated into seven groups of three) has been labelled small by some of my fellow students. However, the reality was that it took a long period of time to set up, conduct, transcribe and analyse twenty-one interviews. While the sample size could have been extended indefinitely, there are numerous constraints preventing that (such as 
thesis submission limitations). The focus was always on getting a rich source of data and I believe that twenty-one interviews were an appropriate sample size given the practical constraints of this thesis.

\section{Opportunities for future research}

In addition to the research options which were mentioned to overcome the limitations, the findings have presented gaps in literature and presented opportunities for future research. The two key opportunities for research are summarised below.

\section{Intervention}

In 2010 the New Zealand government bailed out the failing South Canterbury Finance to the value of $\$ 900$ Million, which has recently increased to $\$ 1.2$ Billion (NZ) and the time of writing the New Zealand government was considering bailing out AMI Insurance, which is struggling to repay coverage after two large earthquakes in a six month period. Across the world national governments have rescued companies such as General Motors, AIG, RBS, Lloyds TSB and the entire Irish Banking sector. The intervention contradicts the idea that governments should not intervene in the market place, but the rationale for these interventions was to prevent market failure. However, the consequence of this intervention is that governments are heavily indebted and have large and sometimes bad investments in the private sector. And it now seems that governments need bailouts. These events present the opportunity for future research into the relationship between business and government. There are fundamental questions about whether governments should be involved in business, and when a business is too big to fail. Research could also look at the patterns emerging across the planet especially in the context of Governments supporting national champions (businesses backed by governments) from countries like China and Brazil and how businesses and governments from developed countries should respond.

\section{The darkest day}

The Canterbury earthquake on the $22^{\text {nd }}$ of February, which caused massive destruction and loss of life in the city of Christchurch, gave me an interesting insight on the role of business. In the immediate aftermath of the earthquake, commerce faded to irrelevance as basic instincts and human life took priority. In the days following the earthquake businesses around the country participated voluntary in the rescue and recovery effort. Air NZ offered very cheap domestic and international flights and Fonterra, a powerful Dairy Cooperative, used its milk tankers to 
transport water to Christchurch (TVNZ Business, 2011). But there were also some examples of businesses or individuals taking actions that the media portrayed as an exploitation of the crisis. The massive damage to the Christchurch CBD meant a dramatic decline in the availability of office space. In a normal market, huge demand for something which is the subject of a supply shock results in enormous price increases. And in this case, some landlords increased rents significantly and were vilified by the mayor who said they were "looting by another name" (New Zealand Herald, 2011). This example was tempting to use in my thesis, but the scope of this research focused on the economic crisis that started in 2008. But in the context of the Christchurch earthquake and the Japanese earthquake, tsunami and nuclear crisis there is a clear opportunity to look at when a business should be involved and how they should be involved as well as looking at how a business manages it priorities in the face of a domestic crisis.

\section{Conclusion}

The purpose of this research was to understand more about the role and responsibilities of business. The recession has provided the lens through which the role and responsibilities of business can be understood. This research has suggested that the purpose of business is to make money and that a responsible business will comply with the law, satisfy customers, act in self interest, avoid causing harm to others and, if desired, engage in strategic social responsibility. This supports the literature arguing against an extension of CSR. But the crucial contribution of this research to literature is that the economic context does not change the purpose or the responsibilities of business.

I believe that this research has succeeded in its aims and has provided valuable contributions toward the literature on CSR and business strategy. In addition to this, I believe this research has provided some practical contributions through the 'responsible and social business models' and the 'core and peripheral responsibility model' for businesses who wish to understand more about CSR or are thinking about creating a CSR program. 


\section{Appendices}

\section{Appendix A: Research Project Information Sheet \\ RESEARCH PROJECT INFORMATION SHEET}

$<$ Date $>$

$<$ Name $>$

$<$ address line 1>

$<$ address line $2>$

$<$ Address line 3>

\section{RE: THE BUSINESS OF BUSINESS IN A RECESSION (WORKING TITLE)}

Dear <name>,

I am carrying out a research project, for my Masters of Commerce and Administration degree in Management, into the relationship between the recession and business responsibility. I wish to extend an invitation to you to participate in this project and give your thoughts on this matter.

My research project tries to make sense of what society expects from business by looking at what social expectations of business are during a recession. I am inviting business managers, policy makers and consumers to participate in my project in order to address my research questions. My research findings are intended to be published and disseminated at academic conferences.

I would like to conduct an interview with you on this matter. The interview will take no longer than half an hour and can take place at a time and location that is suitable to you. I realise that this represents a commitment of time for you but I value your input highly and believe that it would be incredibly valuable to this research project. If you agree to be interviewed then I will ask you to fill in a consent form that, together with this information sheet, outlines your role in the project and how your rights as a research participant will be respected. I would like to digitally record the interview, but this would only be done with your consent. I can assure you that my supervisor and I will be the only people to view the transcript of the interview. The information provided in the interview will be treated as confidential if you wish it to be so.

Please let me know if you wish to be involved in this research project and I shall arrange a time that suits you. In return for your participation in this study I will provide you with a copy of my findings.

If you have any questions please do not hesitate to contact me.

Yours sincerely,

Isaac Rodgers 
Appendix B : Research Project Participant Consent Form

RESEARCH PROJECT CONSENT FORM

"The Business of Business in a Recession" (WORKING TITLE)

Researcher: Isaac Rodgers, Master of Commerce and Administration student, Victoria Management School, Victoria University of Wellington.

$\square \quad$ I have been given and have understood an explanation of the research project

$\square \quad$ I have had an opportunity to ask questions and have them answered to my satisfaction

$\square \quad$ I understand that I may withdraw myself (or any information I have provided) from this project (before data collection and analysis is complete - estimated to be 1 December 2009) without having to give reasons).

$\square \quad$ I understand that any information I provide will be kept confidential to the researcher, that the published results will not use my name, and that no opinions will be attributed to me in any way that will identify me.

$\square \quad$ I understand that the recording of interviews will be electronically wiped at the end of the project unless I indicate that I would like them returned to me.

$\square \quad$ I would like to receive a summary of the results of this research when it is completed.

OR

$\square \quad$ I do not wish to receive a summary of the results of this research when it is completed.

$\square \quad$ My participation is entirely voluntary. I agree to be interviewed for the purpose of this research.

Signed:

Name (please print clearly):

Organisation:

Date: 
Interview Questions: Consumers

\section{Business Responsibility}

1. What do you think the purpose of business is?

2. What are your expectations of business?

3. Do you think that business has any responsibilities?

- Should business have any responsibilities?

4. Why do you think this is/what are these?

5. As a consumer, what do you think of businesses that are responsible?

- Are you any more or less likely to purchase from these businesses?

6. As a consumer, what do you think of businesses that show no responsibility or are not responsible?

- Are you any more or less likely to purchase from these businesses?

\section{Economic Environment and Business Responsibility}

7. What is the purpose of business is during a recession?

8. What are your expectations of business during a recession?

9. Do you think that business has any responsibility during a recession?

10. A. If businesses have responsibility, what is that responsibility?

B. If businesses do not have/have less responsibility, would you say that their responsibility is what you outlined as the purpose of business?

\section{Economic Environment and Business Context}

11. If a business is profitable during a recession, what, if any, responsibility does it have?

- Does it have additional responsibility?

12. If a business is unprofitable during a recession what, if any, responsibility does it have?

- Does it have less responsibility?

- Is it acceptable for an unprofitable business to cut down on social responsibility?

13. During times of economic responsibility, what is your expectation of business?

14. Any additional comments? 


\section{Business Responsibility}

1. What do you think the purpose of business is?

2. What are your expectations of business?

3. Do you think that business has any responsibilities?

- Should business have any responsibilities?

4. Why do you think this/what are these?

5. As a policy maker, what do you think of businesses that are responsible?

6. As a policy maker, what do you think of businesses that show no responsibility or are not responsible?

\section{Economic Environment and Business Responsibility}

7. What is the purpose of business is during a recession?

8. What are your expectations of business during a recession?

9. Do you think that business has any responsibility during a recession?

10. A. If businesses have responsibility, what is that responsibility?

B. If businesses do not have/have less responsibility, would you say that their responsibility is what you outlined as the purpose of business?

\section{Economic Environment and Business Context}

11. If a business is profitable during a recession, what, if any, responsibility does it have?

- Does it have additional responsibility?

12. If a business is unprofitable during a recession what, if any, responsibility does it have?

- Does it have less responsibility?

- Is it acceptable for an unprofitable business to cut down on social responsibility?

13. During times of economic responsibility, what is your expectation of business?

14. Any additional comments? 


\section{Business Responsibility}

15. What do you think the purpose of business is?

16. What are your expectations of business?

- Do your expectations of your own business differ from that of competitors or other businesses?

17. Do you think that business has any responsibilities?

- Should business have any responsibilities?

18. Why do you think this/what are these?

19. As a business manager, what do you think of businesses that are responsible?

20. As a business manager, what do you think of businesses that show no responsibility or are not responsible?

\section{Economic Environment and Business Responsibility}

21. What is the purpose of business is during a recession?

22. What are your expectations of business during a recession?

23. Do you think that business has any responsibility during a recession?

24. A. If businesses have responsibility, what is that responsibility?

B. If businesses do not have/have less responsibility, would you say that their responsibility is what you outlined as the purpose of business?

\section{Economic Environment and Business Context}

25. If a business is profitable during a recession, what, if any, responsibility does it have?

- Does it have additional responsibility?

26. If a business is unprofitable during a recession what, if any, responsibility does it have?

- Does it have less responsibility?

- Is it acceptable for an unprofitable business to cut down on social responsibility?

27. During times of economic responsibility, what is your expectation of business?

28. Any additional comments? 


\section{Bibliography}

Abate, T. (2009, April 12). New Frugality could become a habit for strapped shoppes. San Francisco Chronicle .

Aitkin, B., McLay, G., \& Hodge, B. (2006). Torts in New Zealand. Melbourne: Oxford University Press.

Alexander, T. (2009). Why we are Less Munted. National Party Lower North Island Conference. Wellington.

Alsop, R. (2002). Perils of Corporate Philanthropy: Touting Good Works Offends the U.S. Public, but Reticence Is Misperceived as Inaction. Asian Wall Street Journal , 10.

Andrews, K. (1980). The Concept of Corporate Strategy. Homewood; IL: Irwin.

Ansoff, I. (1991). Critique of Henry Mintzberg's "The Design School: Reconsidering the basic premises of strategic managment. Strategic Management Journal , 12 (6), 449-462.

Aupperle, K., Carroll, A., \& Hatfield, J. (1985). An Empirical Examination of the Relationship between Corporate Social Responsibility and Profitability. Academy of Management Journal , 28 (2), 446-463.

Bank of New Zealand. (2011, March 23). BNZ Leadership Team. Retrieved March 23, 2011, from BNZ: www.bnz.co.nz

Barnett, M. (2007). Stakeholder Influence Capacity and the Variability of Financial Returns to Corporate Social Responsibility. Academy of Management Review , 32 (3), 794-816.

Barry, D., \& Elmes, M. (1997). Strategy Retold: Toward a narrative view of strategic discourse. Academy of Management Review , 22 (2), 621-633.

Barry, N. (1999, June 23). Ignorance, misunderstanding drive business ethics moralism. NZ Herald . Auckland, New Zealand: NZ Herald.

BBC. (2009, 03 12). Madoff admits $\$ 50 b n$ fraud scheme. Retrieved 05 20, 2009, from BBC News: http://news.bbc.co.uk

Beardsley, S., Enriquez, L., \& Nuttal, R. (2008). Managing Regulation in a new era. McKinsey Quarterly.

Bent, N. (2008, September 26). True CSR is recession-proof. PR Week, p. 15.

Bhide, A., \& Stevenson, H. (1990). Why Be Honest if Honesty Doesn't Pay? Harvard Business Review, September-October, 121-129.

Bible Society. (1976). Good News Bible. New York: Collins Bible.

Bielak, D., Bonini, S., \& Oppenheim, J. (2007). CEOs on Strategy and Social Issues. The McKinsey Quarterly , 1-8. 
Bird, R., Hall, A., Momente, F., \& Reggiani, F. (2007). What Corporate Social Responsibility Activities are valued by the market? Journal of Business Ethics , 76 (1), 189-206.

Bonini, S., McKillop, K., \& Mendonca, L. (2007). The trust gap between consumers and corporations. The McKinsey Quarterly (2), 7-10.

Bonini, S., McKillop, K., \& Mendonca, L. (2007). What consumers expect from companies. The McKinsey Quarterly (2), 11-17.

Booth, T. (2008, December). Flight to Value. The Economist: The World in 2009 , p. 127.

Boulstridge, E., \& Carrigan, M. (2000). Do consumers reall care about corporate responsibility? Highlighting the attitude-behaviour gap. Journal of Communication Management , 4 (4), 355-368.

Bowman, E., \& Haire, M. (1975). A strategic posture towards CSR. California Management Review , 18 (2), 49-58.

British American Tobacco (New Zealand). (2007). Social Report 2007. Auckland: British American Tobacco.

Burke, L., \& Logsdon, J. (1996). How Corporate Social Responsibility Pays Off. Long Range Planning , 29 (4), 495-502.

Burrell, G., \& Morgan, G. (1979). Sociological Paradigms and Organisational Analysis . Heinemann.

Caddie, M. (1998, 12 18). Dick Hubbard and Businesses for Social Responsibility. Retrieved 03 10, 2009, from NZINE: www.nzine.co.nz

Campbell, J. (2007). Why would corporations behave in socially responsible ways? An institutional theory of corporate social responsibility. Academy of Management Review , 32 (3), 946-967.

Carrigan, M., \& Atalla, A. (2001). The myth of the ethical consumer - do ethics matter in purchase behaviour? Journal of Consumer Marketing , 18 (7), 560-577.

Carrol, A. (1999). Corporate Social Responsibility: Evolution of a Definitional Construct. Business and Society , 38 (3), 268-295.

Carroll, A. (1979). A Three-Dimensional Conceptual Model of Corporate Performance. The Academy of Management Review , 4 (4), 497-505.

Cassell, C., Symon, G., Buehring, A., \& Johnson, P. (2006). The role and status of qualitative methods in management research: an empirical account. Management Decision , 44 (2), 290-303.

Chevron. (2011, March 5). The Economist , pp. 2-3.

Cho, D., \& Brady, D. (2009, May 13). Officials Knew of AIG Bonuses Months Before Firestorm. Retrieved May 26, 2009, from Washington Post: http://www.washingtonpost.com 
Choi, Y., \& Ying-Hsuan, L. (2009). Consumer Response to crisis: Exploring the concept of involvement in Mattel product recalls. Public Relations Review, 35, 18-22.

Clayton, T. (2009, May 09). Fair Trade Sales. Auckland: TV3.

Cogman, D. (2002). Controversy Incorporated. McKinsey Quarterly (4).

Connolly, J., \& Prothero, A. (2008). Green Consumption: Life-politics, risk and contradications. Journal of Consumer Culture , 8 (1), 117-145.

Consumer. (2006, May 6). Telecom's network to be unbundled. Retrieved June 2, 2009, from Consumer: http://www.consumer.org.nz

Cook, J., McGann, C., \& Pope, C. (2005, 05 07). Microsoft now backs gay rights bills: Reversal follows close vote in state Senate to extend protections. Retrieved May 26, 2009, from Seattle Post Intelligencer: http://www.seattlepi.com

Creyer, E., \& Ross, W. (1997). The Influence of firm behaviour on purchase intention: do consumer really care about business ethics. Journal of Consumer Marketing , 14 (6), 421 432.

Creyer, E., \& William, R. J. (1996). The impact of Corporate Behaviour on Perceived Product Value. Marketing Letters , 7 (2), 173-185.

Davis, I. (2005). What is the business of business? McKinsey Quarterly (3), 105-113.

Davis, K. (1973). The case for and against business assumption of social responsibilities. Academy of Management Journal , 16 (1), 312-322.

Dawkins, J. (2004). Corporate Responsibility: The communication challenge. Journal of Communication Management , 9 (2), 108-119.

Di Norcia, V., \& Tigner, J. (2000). Mixed Motives and Ethical Decisions in Business. Journal of Business Ethics , 25, 1-13.

Donaldson, T., \& Preston, L. (1995). The Stakeholder Theory of the Corporation: Concepts, Evidence and Implications. Academy of Management Review , 20 (1), 65-91.

Encyclopedia Britannica. (2009). Libertarianism. Retrieved 05 26, 2009, from Encyclopedia Britannica: http://www.britannica.com/EBchecked/topic/339321/libertarianism

Favaro, K., Romberger, T., \& Meer, D. (2009). Five Rules for Retailing in a Recession. Harvard Business Review , April, 64-72.

Flanagan, M. (2009, May 06). RBS chief to quit - with no bonus or bumper pension. Retrieved May 26, 2009, from The Scotsman: http://thescotsman.scotsman.com/

Flavelle, C. (2009, February 15). Responsibility is still Good for Business. The Washington Post

Freeman, E. (1984). Strategic Management: A Stakeholder Approach. Marschfield: MA: Pitman Publishing. 
Freeman, E., \& Phillips, R. (2002). Stakeholder Theory: A libertarian Defense. Business Ethics Quarterly, 12 (3), 331-349.

Friedman, M. (1970, September 13). The Social Responsibility of Business is to Increase its Profits. The New York Times Magazine .

Gamble, A., \& Kelly, G. (2001). Shareholder Value and the Stakeholder Debate in the UK. Corporate Governance , 9 (2), 110-117.

Gibbs, N. (2009, April 15). The Great Recession: America Becomes Thrift Nation. Time .

Gioia, D., \& Pitre, E. (1990). Multiparadigm Perspectives on Theory Building. Academy of Management 15 (4) , 584-601.

Goodpaster, K. (1991). Business Ethics and Stakeholder Analysis. Business Ethics Quarterly, 1 (1), 53-72.

Hernandez, I. (2009, March 25). Holding onto CSR in the recession. Retrieved May 10, 2009, from SME Web: http://www.smeweb.com

Hofstede, G. (1984). Cultural Dimensions in Management and Planning. Asia Pacific Journal of Management , 1 (2), 81-99.

Hubbard, D. (1999, June 23). Profit Maximisation inadequate goal. NZ herald . Auckland, New Zealand: NZ Herald.

Hurn, B. (2008). Ethics in International Busines. Industrial and Commercial Training , 40 (7), 347-354.

Husted, B., \& Allen, D. (2007). Strategic Corporate Social Responsibility and Value Creation among Large Firms: Lesson from the Spainish Experience. Long Range Planning , 40 (1), 594-610.

Hyundai Assurance New Zealand. (2009). Hyundai Assurance. Retrieved 5 10, 2009, from Hyundai: http://www.hyundaiassurance.co.nz/

Ihlen, O. (2008). Mapping the Environment for Corporate Social Responsibility. Corporate Communications: An International Journal , 13 (2), 135-146.

Inkpen, A., \& Choudary, N. (1995). Seeking Strategy where it is not: Toward a theory of strategy absence. Strategic Management Journal , 16 (4), 313-323.

Internal Revenue Service. (2005, August 29). KPMG to Pay $\$ 456$ Million for Criminal Violations. Retrieved 05 17, 2009, from Internal Revenue Service: United States Department of the Treasury: http://www.irs.gov/

International Organization for Standardization. (2008). ISO and Social Responsibility. Retrieved 05 29, 2009, from International Organization for Standardization: http://www.iso.org/

Johnson, G., Scholes, K., \& Whittington, R. (2005). Exploring Coporate Strategy: Text and cases. England: Pearson Education Limited. 
Kato, D. (2009, April 13). Will the poor economy permanently affect how we shop? Tribune News Service.

Kennedy, E., \& Lawton, L. (1998). Religiousness and Business Ethics. Journal of Business Ethics , $17(1)$, 163-175.

Kern, K. (2006). Corporate Complicity in Congo's War. TIKKUN , 21 (2), 38-40, 67.

Kerr, R. (1998). Business as a Vocation. Auckland Institute of Technology Commerce Students Breakfast Club, (pp. 2-11). Auckland.

Kerr, R. (2004). Business, Profits and Economic Progress. Insurance Brokers of New Zealand, (pp. 1-9). Rotorua.

Kerr, W. (2009). Recession, International Trade and the Fallacies of Composition. The Estey Centre Jounral of International Law and Trade Policy , 10 (1), 1-11.

Kolk, A., \& Pinkse, J. (2007). Towards strategic stakeholder management? Integrating perspectives on sustainability challenges such as corporate responses to climate change. Corporate Governance , 7 (4), 370-378.

Kozinets, R., \& Handelman, J. (2004). Adversaries of Consumption: Consumer Movements, Activism, and Ideology. Journal of Consumer Research , 31, 691-704.

Lemke, D., \& Schminke, M. (1991). Ethics in Declining Organisations. Business Ethics Quarterly , 1 (3), 235-248.

Mayan, M. (2001). An Introduction to Qualitative Methods: A Training Module for Students and Professionals. Edmonton: International Institute for Qualitative Methodology.

McGuire, J., Sudgren, A., \& Schnessweis, T. (1988). Corporate Social Responsibility and Firm Financial Performance. Academy of Management Review , 31 (4), 854-872.

McMahon, T. (1991). A Reaction to Vogel's The Ethical Roots of Ethical Business. Business Ethics Quarterly , 1 (2), 211-222.

McWilliams, A., Van Fleet, D., \& Cory, K. (2002). Raising rivals' costs through political strategy: An extension of resource-based theory. Journal of Management Studies , 39, 603-609.

Miller, K., \& Sturdivant, F. (1977). Consumer Response to Socially Questionable Behaviour: An Empirical Test. Journal of Consumer Research , 4, 1-7.

(1987). The Strategy Concept: Five P's for Strategy and the Strategy concept II: Another look at why Organizations need strategies. In H. Mintzberg, \& C. 2. Vogel (Ed.), Organizational Approaches to Strategy (pp. 7-28). New York: Harper \& Row.

Mohr, L., Webb, D., \& Harris, K. (2001). Do Consumers expect companies to be socially responsible? The impact of Corporate Social Responsibility on Buying Behaviour. The Journal of Consumer Affairs , 35 (1), 45-72.

Mokhiber, R., \& Weissman, R. (2005). The 10 Worst Corporations of 2005. Multinational Monitor , 26 (11/12), 10-24. 
Montiel, I. (2008). Corporate Social Responsibility and Corporate Sustainability. Organization and Environment , 21 (3), 245-269.

New Zealand Herald. (2011, March 12). Editorial: City's recovery depends on rent control. Retrieved March 2011, 13, from www.nzherald.co.nz: www.nzherald.co.nz

Novac, M. (1982). The Spirit of Democratic Capitalism. New York: Simon \& Schuster Publication.

O'Leary, Z. (2004). The Essential Guide to Doing Research. London: Sage Publications.

Paderon, E. (1991). Catholic Social Teaching and Business Ethics:A Search for Moral Foundations. Int. J. Value-Based Management , 4 (2), 123-132.

Parket, R., \& Eibert, H. (1975). Social Responsibility: The Underlying Factors. Business Horizons , 18 (1), 5-10.

Porter, M., \& Kramer, M. (2006). Strategy and Society: The link between competitive advantage and Corporate Social Responsibility. Havard Business Review , 84 (12), 78-92.

Quelch, J., \& Jocz, K. (2009). How to Market in a Downturn. Harvard Business Review , April, 52-63.

Quinn, J. (1978). Strategic Change: Logical Incrementalism. Sloan Management Review , 20 (1), 7-19.

Reuters. (2009, April 1). 2 Ex-KPMG Managers Sentenced Over Tax Shelters. Retrieved May 17, 2009, from New York Times: http://www.nytimes.com

Rodgers, I. (2008). Strategy and Environmental Corporate Social Responsibility: Creating Value Responsibly or perfecting the art of greenwash? Wellington.

Roman, R., Hayibor, S., \& Agle, B. (1999). The Relationship between Social and Financial Performance: Repainting a Portrait. Business and Society , 38, 109-125.

Rosenwald, M. (2009, April 16). When You're Flush, but Acting Flat Broke; Social Cues Can Drive a Downturn. Retrieved May 19, 2009, from The Washington Post: http://www.washingtonpost.com

Schendel, D. (1985). Strategic Marketing and Strategic Management: What's Strategic about either one? In H. Thomas, \& D. Gardner (Eds.), Strategic Marketing and Strategic Management (pp. 41-63). New York: Wiley.

Schmitt, J., \& Baker, D. (2008). What We're In For. Projected Economic Impact of the Next Recession , 51 (3), 27-42.

Schroeder, D. (2002). Ethics from the top: top management and ethical business. Business Ethics: A European Review , 11 (3), 260-267.

Smith, C., \& Ward, H. (2007). Corporate Social Responsibility at a Crossroads? Business Strategy Review , 17-21. 
Sproles, G., Geistfeld, L., \& Badenhop, S. (1978). Information Inputs as Influences on efficient consumer decison making. Journal of Consumer Affairs , 12, 88-103.

Stafford, E., \& Hartman, C. (1996). Green Alliances: Strategic Relations Between Business and Environmental Groups. Business Horizons, March-April, 50-59.

Statistics New Zealand. (2009, June 1). Main Indicators. Retrieved June 1, 2009, from Statistics New Zealand Home: http://www.stats.govt.nz

Statistics New Zealand. (2011, March 13). Main Indicators. Retrieved March 13, 2011, from Statistics New Zealand Home: http://www.stats.govt.nz

Strong, C. (1996). Features Contributing to the growth of ethical consumerism - a preliminary investigation. Marketing Intelligence and Planning , 14 (5), 5-13.

Teather, D. (2005, 05 04). Controversial business. Retrieved 05 26, 2009, from Guardian: http://www.guardian.co.uk/

Telegraph, T. (2008, September 26). Nicolas Sarkozy calls for overhaul of capitalism. Retrieved March 4, 2011, from Telegraph: http://www.telegraph.co.uk

The Economist. (2009, May 16-22). A stress test for Good Intentions. The Economist , pp. 6768.

The Economist. (2009, May 23-29). Economic and Financial Indicators. The Economist , p. 89.

The Economist. (2011, March 12). Economic and financial indicators. The Economist , p. 101.

The Economist. (2009, April 2nd). From buy, buy to bye-bye. The Economist .

The Economist. (2008, May 29). Pistol pointed at the heart. Retrieved April 20, 2009, from Will high oil prices tip the economy into recession?: http://www.economist.com

Touraine, A. (1977). The Self-Production of Society. Chicago: University of Chicago Press.

Treanor, J., \& Wintour, P. (2009, 02 27). Sir Fred Goodwin: minister approved my pension and I'm keeping it. Retrieved 05 26, 2009, from Guardian: http://www.guardian.co.uk/

Trudel, R., \& Cotte, J. (2009). Does it pay to be Good? MITSloan Management Review , 50 (2), 61-68.

TVNZ Business. (2011, March 2). Fonterra gives millions to quake relief. Retrieved March 05, 2011, from TVNZ: www.tvnz.co.nz

Ullman, A. (1985). Data in Search of a Theory: A critical examination of the relationship among social performance, social disclosure, and economic performance. Academy of Management Review, 10, 450-477.

Vogel, D. (1991). The Ethical Roots of Business Ethics. Business Ethics Quarterly , 1 (1), 101 120.

Votaw, D. (1973). Genius becomes rare. In D. Votaw \& S.P. Sethi)Eds.) The corporate dilemma. Englewood Cliffs, NJ: Prentice Hall. 
Wade, M. (2009, 05 19). 18 police officers investigated attack on Sir Fred Goodwin's house. Retrieved 05 26, 2009, from TimesOnline: http://www.timesonline.co.uk/

Welford, R. (2008). The Future of CSR: Issues for the next decade. CSR Asia Weekly , 4 (42).

Wellington. (2009). Facts and Stats. Retrieved Feburary 5, 2010, from Wellington New Zealand: http://live.wellingtonnz.com/page/facts-and-stats.aspx

Wells, J. (2009, April 20). How Recession changed the green marketplace. Retrieved May 10, 2009, from The Globe and Mail: http://www.theglobeandmail.com

Williams, G., \& Zinkin, J. (2008). The effect of culture on consumer's willingness to punish irresponsible corporate behaviour: applying Hofstede's typology to the punishment aspect of corporate social responsibility. Business Ethics: A European Review , 17 (2), 210-226.

World Health Organization. (2009). 10 facts about tobacco and second-hand smoke. Retrieved 05 31, 2009, from World Health Organization: http://www.who.int

Wren, D. (2000). Medieval or Modern: A Scholastic's View of Business Ethics, circa 1430. Journal of Business Ethics , 28 (1), 109-119.

Young, A. (2006, May 16). The Telecom leak: Shoot the messenger. Retrieved June 2, 2009, from The New Zealand Herald: http://nzherald.co.nz

Zairi, M., \& Peters, J. (2002). The impact of social responsibility on business performance. Managerial Auditing Journal , 17 (4), 174-178.

Zimmerman, R. (1996). The Law of Obligations: Roman Foundations of the Civil Tradition. Oxford: Oxford University Press. 